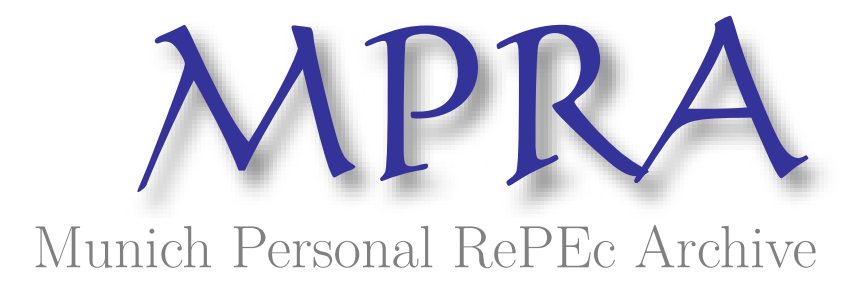

\title{
How lead exposure relates to temporal changes in IQ, violent crime, and unwed pregnancy
}

Nevin, Rick

15 September 1999

Online at https://mpra.ub.uni-muenchen.de/35324/

MPRA Paper No. 35324, posted 11 Dec 2011 02:01 UTC 


\title{
How Lead Exposure Relates to Temporal Changes in IQ, Violent Crime, and Unwed Pregnancy
}

\author{
Rick Nevin \\ SEPTEMBER 15, 1999
}

Notice: This is an author's version of a work that was accepted for publication by Environmental

Research. Changes that resulted from the publishing process, such as peer review, editing, corrections, structural formatting, and other quality control mechanisms may not be reflected in this document. Changes may have been made to this work since it was submitted for publication. A definitive version was subsequently published in Environmental Research, Volume 83, Issue 1, May 2000, Pages 1-22. 


\section{How Lead Exposure Relates to Temporal}

\section{Changes in IQ, Violent Crime, and Unwed Pregnancy}

This study compares changes in children's blood lead levels in the United States with subsequent changes in IQ, based on norm comparisons for the Cognitive Abilities Test (CogAT) given to representative national samples of children in 1984 and 1992. The CogAT norm comparisons indicate shifts in IQ levels consistent with the blood lead to IQ relationship reported by an earlier study and population shifts in average blood lead for children under age six between 1976 and 1991. The CogAT norm comparisons also support studies indicating that the IQ to blood lead slope may increase at lower blood lead levels. Furthermore, long term trends in population exposure to gasoline lead were found to be remarkably consistent with subsequent changes in violent crime and unwed pregnancy. Long term trends in paint and gasoline lead exposure are also strongly associated with subsequent trends in murder rates going back to 1900. The findings on violent crime and unwed pregnancy are consistent with published data describing the relationship between IQ and social behavior. The findings with respect to violent crime are also consistent with studies indicating that children with higher bone lead tend to display more aggressive and delinquent behavior. This analysis demonstrates that widespread exposure to lead is likely to have profound implications for a wide array of socially undesirable outcomes.

\section{Key Words:}

Lead Exposure, IQ, Violent Crime, Unwed Pregnancy 


\section{INTRODUCTION}

Many studies provide evidence of an inverse relationship between lead exposure and cognitive abilities (National Research Council). There is, however, disagreement about the IQ to blood lead slope (IQ points lost per one ug/dl increase in blood lead) and the influence of confounding variables (Schwartz; Pocock et al.). There is strong evidence that young children face the greatest risk of $I Q$ losses due to lead exposure, especially during the first three years of life when basic cognitive abilities develop (Schwartz). Cognitive losses due to lead exposure during the first three years of life appear to be most evident in IQ tests taken some years later, around age 10 or older, when IQ scores are more stable and predictive of future outcomes (National Research Council; Schwartz). There is no consensus, however, on whether lead exposure is more strongly associated with verbal IQ, mathematical skills, or performance IQ (National Research Council).

In addition to disagreements about the statistical significance of IQ losses due to lead exposure after controlling for confounding variables, there is a separate debate about the public policy significance of studies showing only a fraction of an IQ point lost per one ug/dl increase in blood lead. One argument in favor of public policy initiatives to reduce lead exposure is that small differences in mean IQ due to lead exposure can result in substantial differences in extreme values of the IQ and blood lead distributions. Differences in IQ have also been associated with differences in educational attainment and average lifetime earnings (National Research Council).

A better understanding of the specific nervous system impacts of lead may be obtained from new epidemiological or laboratory studies, but the public policy debate has been largely resolved, with policy initiatives already successfully implemented to reduce lead exposure. The second and

third National Health and Nutrition Examination Surveys (NHANES II and III) show that blood lead levels for children under age six declined by 75 percent between 1976 and 1991, due to declines 
in lead in gasoline and solder in food and soft drink cans (Pirkle, et al.). This dramatic decline in national blood lead levels offers a new research perspective on both the statistical significance of lead's association with IQ after adjusting for covariates, and the public policy significance of IQ changes due to lead exposure. Has the decline in childhood blood lead since 1976 resulted in any subsequent increase in IQ levels that cannot be explained by confounding variables? If IQ levels have increased, what slope estimate for the IQ to blood lead relationship is suggested by this increase in IQ? Finally, have changes in blood lead been followed by subsequent changes in social behavior - with public policy significance - that might be associated with extreme values of the IQ and blood lead distributions?

\section{Confounding Variables and the IQ to Blood Lead Slope}

Most studies attempt to control for established effects on IQ scores such as socioeconomic status (SES), parental education and parental IQ. Many studies also incorporate the Home Observation for the Measurement of the Environment (HOME) inventory, which measures a child's family environment with respect to intellectual stimulation and parental sensitivity, based on a structured interview and home observation.

"Several of these studies have reported that significant associations between body lead and children's developmental test scores disappear or become marginal when HOME is used as a covariate. [However,] many HOME items can directly reflect the presence of lead and its effect, rather than measuring independent sources of variation in children's development. For example, one of the HOME subscales measures quality of the physical environment, including cleanliness. This measure can be related to lead exposure because of lead in household dust" (Banks et al.).

Schwartz's meta-analysis (1994) of the IQ to blood lead relationship examined eight studies that reported full-scale IQ for school age children with data on blood lead levels. Six of these studies 
controlled for both parental IQ and HOME score, and the eight studies together provided a range of low, average, and high SES. Schwartz reported an overall slope of .26 IQ points lost per one $\mathrm{ug} / \mathrm{dl}$ increase in blood lead, but he found a slope of .323 in studies with mean blood lead below $15 \mathrm{ug} / \mathrm{dL}$, and .232 in studies with mean blood lead above $15 \mathrm{ug} / \mathrm{dL}$. The only study in the Schwartz analysis with mean blood lead below $10 \mathrm{ug} / \mathrm{dL}$ reported a slope of .58 IQ points lost per one $\mathrm{ug} / \mathrm{dL}$ increase in blood lead. This last study suggests that an even higher slope might apply to blood lead levels below $10 \mathrm{ug} / \mathrm{dl}$.

A more recent study by Dudek and Merecz (1997) reports a slope of .53 in a population of 380 children with average blood lead of $10.2 \mathrm{ug} / \mathrm{dL}$, after controlling for covariates including mother's education, occupational status, and family income. In this study, blood lead was more strongly associated with verbal IQ than with performance IQ. Although mother's education exerted the greatest influence on a child's IQ, the authors found that higher blood lead was associated with lower IQ for both higher and lower maternal education groups. The authors also found the most rapid deterioration of IQ was observed at blood lead levels between 5 - $10 \mathrm{ug} / \mathrm{dl}$ and $11-15 \mathrm{ug} / \mathrm{dl}$, consistent with the Schwartz finding of an increasing slope at lower blood lead levels.

Another meta-analysis, by Pocock et al., found that five prospective studies supported an IQ to blood lead slope estimate of .185 , and 14 cross-sectional blood lead studies supported a slope estimate of .175 after the removal of one extreme value. A negative association was also found in seven cross-sectional tooth lead studies. All five of the prospective studies controlled for mother's IQ and HOME score, and most of the cross-sectional studies controlled for either mother's IQ or mother's education. Pocock and colleagues observed "no striking relation between the studies' mean blood lead and the magnitude of the lead-IQ association" (Pocock et al.), but the data in this analysis do show higher IQ to blood lead slopes for studies of children with average blood lead below $10 \mathrm{ug} / \mathrm{dL}$. Figure 1 (Pocock et al.) shows that most studies of children's blood lead and 
tooth lead report an average loss of one to two IQ points per doubling of body lead burden (10 to $20 \mathrm{ug} / \mathrm{dL}$ blood lead or 5 to $10 \mathrm{ug} / \mathrm{g}$ tooth lead), but the four studies of children with average blood lead levels below $10 \mathrm{ug} / \mathrm{dL}$ show an average loss of about four IQ points per doubling of body lead burden.

Figure 1

Synthesis of 26 Studies Relating Lead Concentrations to IQ

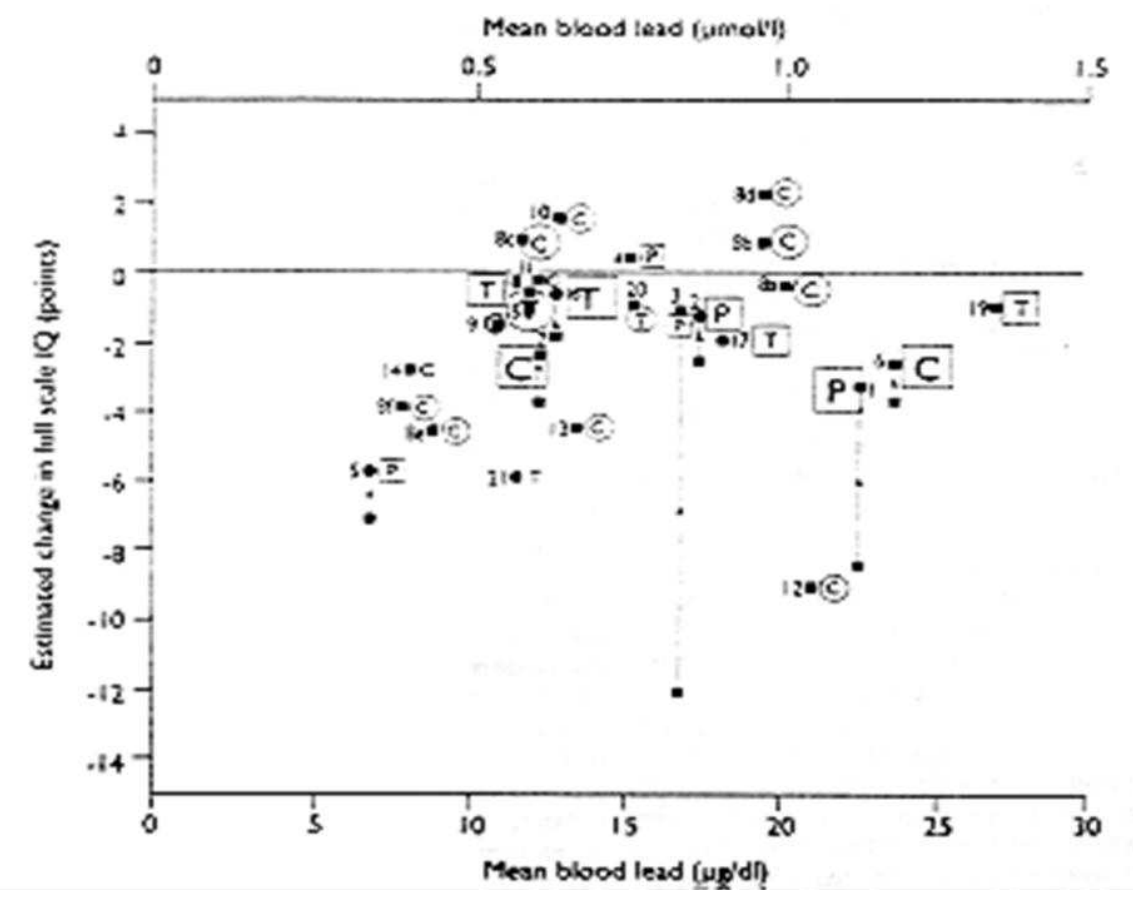

"For each study the estimated change in IQ for a specific doubling of body lead burden (10 to $20 \mathrm{ug} / \mathrm{dl}$ blood lead or 5 to $10 \mathrm{ug} / \mathrm{g}$ tooth lead) is plotted against the study's mean blood lead concentration. Study types: $\mathrm{P}=$ prospective, $\mathrm{C}=$ cross sectional blood lead, $\mathrm{T}=$ cross sectional tooth lead. Three sizes of letter represent the size of the study ( $>400,200-400$, or $<200$ children). Substantial or partial adjustment for confounders is indicated by a square or circle respectively; the influence of substantial adjustments is shown by the arrowed lines." (Pocock et al).

Pocock and colleagues also caution that it is difficult to draw clear conclusions about a causal relationship between lead exposure and $I Q$, in part because of confounding variables. One commentary on this analysis, however, suggests that

"the authors ignore the phenomenon of shared variance and assign the decrease in effect size when confounders are controlled exclusively to the confounder. Confounders can have a direct affect on outcome; they can also operate through increasing lead concentration.

Poverty affects cognition. It also results in families living in homes with higher lead content 
and surfaces that have deteriorated. Lower parental intelligence and poor care taking, in addition to directly affecting the cognition of offspring, may lead to increased absorption of lead" (Needleman).

\section{Temporal Trends in IQ}

IQ scores measure the cognitive ability of any individual relative to the rest of the population. Therefore, a temporal shift in the IQ distribution is apparent only when a new population norm, or standard, is established for a new or revised IQ test based on the distribution of test scores from a new representative sample of the population. If most people have IQ scores relative to this new standard that are lower than their IQ scores on an older IQ test (relative to an older population sample) then this suggests an upward shift in the IQ distribution for the population. In other words, an increase in cognitive ability for the population as a whole establishes a higher standard for measuring the IQ of any individual, so that a typical individual will have a lower IQ score relative to this new, higher standard.

By comparing old and new population standards for IQ tests over time, James Flynn has documented extensive evidence of rising IQ scores in twenty nations (Flynn, 1994). The IQ gains reported by Flynn are largest on culture-reduced tests, like the Ravens test; less on tests that combine performance and verbal scales, like the Wechsler and Stanford-Binet tests; and lowest on verbal-math tests, like the Otis test (Flynn, 1987).

Culture-reduced tests measure fluid intelligence, or on-the-spot problem-solving ability, as opposed to learned or acquired knowledge.

"Tests of spatial visualization, figural similarities and sequences, figure classification and generalization are the purest measures of fluid intelligence; tests such as number series and verbal analogies are less clear measures" (Flynn, 1994). 
Tests that also measure crystallized intelligence

"place less emphasis on on-the-spot problem solving and more on whether someone has acquired the skills, or general knowledge, or vocabulary we would expect an intelligent person to gain in a normal life. IQ gains over time diminish as tests get farther and farther from measuring fluid intelligence. The continuum from fluid to crystallized runs from tests with culture-reduced content, through performance tests, through verbal tests, to pure vocabulary tests. Verbal tests always involve spoken or written language. Performance tests involve an operation, using blocks to copy a design, arranging pictures in a logical sequence" (Flynn, 1994).

In the United States, Flynn reports an average increase of 0.3 IQ points per year from 1932 to 1989 , at a roughly uniform rate and at similar rates for all ages, on the Wechsler and StanfordBinet tests that measure a mix of fluid and crystallized intelligence. Furthermore, comparing Stanford-Binet scores by soldiers in 1918 with the standardization sample in 1932 indicates that this steady rise in IQ in the United States began no later than 1918 (Flynn, 1994).

In Japan, Austria, West Germany, and France, Wechsler scores for children ages 6 to 15 show gains of .38 to .84 IQ points per year from the early 1950 s through the early 1980 s. Children ages 8 to 12 in Switzerland show a Wechsler gain of .65 IQ points per year from 1956 to 1977 , but only .19 points per year from 1977 to 1984 (Flynn, 1987).

In France, Belgium, and The Netherlands, the culture-reduced portion of military examination tests, given to young men around the age of 18 , show gains of .67 to 1.0 IQ points per year from the early 1950 s through the early 1980s. Similar military tests in Norway show gains of .63 IQ points per year from 1954 to 1968, but only .22 IQ points per year from 1968 to 1980 (Flynn, 1987). 
Verbal-math scores on the Belgium and France military tests show gains of .41 and .37 IQ points per year, respectively. The verbal-math scores on the Norway military tests show gains of .58 IQ points per year from 1954 to 1968, but show losses of .13 IQ points per year from 1968 to 1980. Children ages 10 to 13 in New Zealand show verbal test gains of .24 IQ points per year from 1936 to 1968 . In Canada, 10-year-old children show verbal test gains of .63 from 1958 to 1978, but 13-year-old children show lesser gains of .35 IQ points per year over the same time period (Flynn, 1987).

Flynn examines several possible explanations for rising IQ scores over time, including advances in education and improved nutrition. He finds that different theories may explain IQ gains in certain countries over specific time intervals, but no single theory adequately explains all of the data on IQ gains.

"Some day sufficient data may allow us to see why some tests show higher gains than others, why some countries show higher gains than others [resulting in] a better theory of intelligence and better vehicles for measuring it." (Flynn, 1987).

\section{Temporal Trends in Lead Exposure}

Changes in lead exposure should be considered as another variable that could be associated with rising IQ scores over time. Gasoline lead exposure cannot explain the long-term IQ trend because it did not begin until the 1920s and did not peak until the early 1970s. Exposure to both paint lead and one major source of lead in drinking water, however, has declined throughout most of this century in a manner that could have contributed to the long-term rise in IQ levels.

"The period during which leaded paint had the highest amounts of lead and posed the worst toxicity risk in the United States was from around 1875 to the 1940 s ... [and] the 
problem with lead connectors and service pipe is associated principally with old housing, built around 1920 or before." (National Research Council).

Prior to 1906 practically all house paints contained white lead (Mattiello). Table 1 shows data on white lead consumption, by decade, from 1914-78 (US Geological Survey). White lead data for 1914-23 in Table 1 are used to estimate 1920s consumption because 1914 is the earliest year of available data. A small percentage of white lead was consumed in ceramics, chemicals, greases, plasterizers and stabilizers but the majority of white lead was used in paint (Gipe). In fact, the paint industry accounted for about 95 percent of total white lead pigment consumption during the 1930s (Mattiello). Table 1 also shows consumption of tetraethyl lead in gasoline from 1941-87 and consumption of red lead and litharge from 1920-78 (US Geological Survey). Litharge is primarily used in storage batteries. Red lead was used mostly for ceramics, lubricants, petroleum, rubber, glass, and other industrial applications, and was used very little in the paint industry as varnishes, enamels and glazes (Gipe).

The limited application of red lead by the paint industry was often as a rust-inhibiting primer coat for exterior metals, including bridges and automobiles, which were covered by a finish coat of different composition (Mattiello). The industrial uses of red lead are especially apparent in the data for the 1940s when there was a sharp increase in red lead and litharge consumption during World War II, while housing starts were sharply lower during the same period. The increase in red lead consumption in 1941 was specifically associated with efforts by the automobile industry to produce a record number of vehicles before converting to war production (US Geological Survey). Industrial lead consumption can result in paraoccupational lead exposure for young children (lead brought home from work exposure, usually on work clothes) but white lead used in house paint would have the far more pervasive effect on children's blood lead levels. Therefore, the white lead data for each decade in Table 1 are divided by total occupied units at the end of 
each decade to estimate the change in paint lead exposure per housing unit from 1914 through 1978. By this measure, it is apparent that average childhood exposure to lead in paint began to decline at least as far back as the 1920s.

Table 1

Lead in Paint per Occupied Unit, by Decade, 1920-1978

\begin{tabular}{|c|c|c|c|c|c|}
\hline & \multicolumn{3}{|c|}{ Lead Consumption (tons 000) } & \multirow{2}{*}{$\begin{array}{l}\text { Decade-End } \\
\text { Occupied } \\
\text { Units (MM) }\end{array}$} & \multirow{2}{*}{$\begin{array}{l}\text { Paint Lead } \\
\text { per Unit } \\
\text { (pounds) }\end{array}$} \\
\hline & $\begin{array}{l}\text { White } \\
\text { Lead }^{*}\end{array}$ & $\begin{array}{l}\text { Red Lead } \\
\text { \& Litharge* }\end{array}$ & $\begin{array}{l}\text { Tetraethyl Lead } \\
\text { in Gasoline* }\end{array}$ & & \\
\hline 1914-23 & 1,340 & NA & NA & 24.35 & 110 \\
\hline 1920-29 & 1,307 & 356 & NA & 29.91 & 87 \\
\hline 1930-39 & 737 & 421 & NA & 34.86 & 42 \\
\hline 1940-49 & 476 & 1,189 & 672 & 42.83 & 22 \\
\hline 1950-59 & 196 & 816 & 1,565 & 53.02 & 7 \\
\hline 1960-69 & 82 & 781 & 2,171 & 63.45 & 3 \\
\hline $1970-80$ & 29 & 625 & 2,430 & 80.39 & 1 \\
\hline $1980-90$ & NA & NA & 662 & NA & NA \\
\hline
\end{tabular}

*US Geological Survey

Although paint lead in older housing units poses a lingering hazard today, the health hazards must have been more acute and more widespread in the years when peeling lead paint was scraped away and replaced with a fresh coat of lead paint. As early as 1839 , research revealed "the clinical course of 1,207 persons with lead colic and the types of work that exposed them to lead. More than 800 of the cases were in painters or workers involved in the manufacture of white or red lead pigments. ... Somewhat later ... reproductive failures and congenital lead poisoning ... not only among female lead workers, but also among the wives of men who worked in the lead trades ... led a British Royal Commission in 1910 to recommend that women be excluded from the lead trades" (National Research Council).

In 1987, an advertisement in England for lead-free enamel emphasized that the product was non-poisonous, in contrast to lead paint. In 1904, research explicitly linked childhood lead poisoning in Australia to children biting their nails and sucking their fingers after exposure to lead paint on walls and railings. The first American case of childhood lead poisoning was reported in 1914, and 17 more cases were published in 1926 (National Research Council). During this same time period, market forces began to reduce the amount of lead used in paint. 
"Paint production data from the Census of Manufacturers indicate that, by 1919, the production of water and calcimin-based paints almost equaled those with white lead. Around 1920, a zinc-based compound known as lithopone came into use as a supplement or replacement for white-lead pigments in interior paints. In the 1930s, titanium dioxide was introduced as a hiding pigment. The production of titanium dioxide pigments equaled that of leaded pigments by the late 1940s and, by the late 1950s, was five times greater. Latex paint came into use in the 1930s and, by the 1950s, was the dominant paint for interior walls. Lead was seldom used with latex paint; it was primarily an additive to oil and alkyd paints" (US Department of Housing and Urban Development, 1970).

Declining childhood exposure to paint lead (and to drinking water lead from lead pipes) could have substantially reduced children's blood lead levels in the United States from the early 1900s through the late 1940s. The declining use of lead in paint throughout this century means that the children living in newer residential units each year were exposed to lead paint on fewer household surfaces and/or to lower concentrations of lead in the lead-based paint that was in their home. Children living in older homes that were well maintained also would have less exposure over time as repainting covered high lead concentration paint with paint that had lower concentrations of lead or no lead at all.

\section{Comparing Temporal Trends in Lead Exposure and IQ}

The likely decline in blood lead over the first half of the $20^{\text {th }}$ century could be a factor in rising IQ scores among adolescents and young adults from 1918 through 1970, covering most of the data reported by Flynn. The Stanford-Binet scores for US soldiers in 1918 could be associated with childhood paint lead exposure around 1900 when practically all house-paints contained white lead. The standardization sample in 1932 could be associated with lead exposure around 1912 when the production of water and calcimin-based paints almost equaled those with white lead, 
and IQ norm comparisons through the early 1970s could reflect the decline in white lead consumption after the 1920s. Evidence of a similar awareness of lead paint hazards over a similar time period in other countries suggests that reduced lead exposure could also be a factor in rising $\mathrm{IQ}$ scores in other countries.

US consumption of tetraethyl lead in gasoline first exceeded the consumption of white lead in the late 1940s, but the expanding use of automobiles probably had very different effects on blood lead levels for different segments of the population from the 1940s through the 1960s. Children in central cities had the greatest exposure to gasoline lead, due to urban traffic congestion, and they realized relatively little benefit from declining levels of lead in paint because older housing units common in central cities had high concentrations of lead in paint from earlier decades. This is particularly true because poorer children have been disproportionately concentrated in central cities, and lower income households are more likely to have paint in poor condition, creating paint chip and lead dust hazards. During the years when gasoline lead was used extensively, children exposed to urban atmospheres and to interior lead paint in their homes had about six times higher daily lead intake than suburban children with minimal lead exposure (US Environmental Protection Agency). Therefore, the blood lead levels of children in urban areas exposed to gasoline lead and to paint lead in older housing probably began to rise as early as the 1940s.

Blood lead levels for most American children, however, may have continued to decline from 1940 through the early 1960s because lower paint lead levels in new suburbs may have more than offset suburban exposure to gasoline lead. The near doubling of occupied units from 1940 to 1970 (as shown in Table 1) reflects the rapid rate of suburban residential construction in the 1950s and 1960s, and families with young children accounted for a disproportionate share of households moving to these new suburbs. Furthermore, children in the 1950s and 1960s almost 
certainly had less paraoccupational lead exposure because the industrial consumption of red lead and litharge also declined over these two decades. Suburban children would also have experienced the greater decline in paraoccupational exposure to the extent that suburban parents were more likely to have jobs with little or no risk of occupational lead exposure. A continuing decline in blood lead levels for suburban children throughout the 1950s and into the 1960s could be a factor in rising average IQ scores among young adults through the 1980s.

By the mid-1960s, US consumption of lead in gasoline far exceeded the consumption of lead in paint, with tetraethyl lead consumption exceeding 200,000 tons per year from 1964 through 1974.

“Ambient airborne lead concentration showed no marked trend from 1965 to 1977.

Decreases from 1977 to 1982 reflect the smaller lead emissions from mobile sources" (US Environmental Protection Agency).

Extensive research demonstrates a strong correlation between blood lead levels and lead consumed in gasoline during the late 1970s, reflecting the combined effects of inhaled air and gasoline lead deposited on food and in household and street dust (Schwartz and Pitcher; US Environmental Protection Agency).

The pervasive effects of US gasoline lead exposure from the mid-1960s through the 1970s suggest that blood lead levels almost certainly rose for most American children during this time period. Therefore, if childhood lead exposure were a significant factor in the long-term rise in IQ scores reported by Flynn, then we would expect to see that rising trend interrupted for Americans born during the 1960s and 1970s. On the other hand, the decline in gasoline lead use and the resulting decline in ambient air lead from 1977 to 1982 resulted in a 75 percent decline in children's blood lead between 1976 and 1991 (Pirkle, et al.). Therefore, if childhood lead 
exposure were a significant factor in rising IQ scores reported by Flynn, then we would expect to see that rising trend accelerate for Americans born after 1982.

A similar pattern of declining paint lead exposure over several decades, followed by a sharp increase in gasoline lead exposure in the 1970s, could explain some of the temporal variation in long-term IQ trends reported for other nations. For example, Swiss children ages 8 to 12 had Wechsler gains of .65 IQ points per year from 1956 to 1977 but only .19 IQ points per year from 1977 to 1984 . The first of these two norm comparisons (1977 relative to 1956) compared a population standard for children born around 1967 with a population standard for children born around 1946. The children born in 1967 had far less childhood paint lead exposure than those born in 1946, and this decrease in paint lead exposure may have only been slightly offset by an increase in gasoline lead exposure. The second Swiss comparison (1984 relative to 1977) compared an IQ norm for children born around 1974 with an IQ norm for children born around 1967. The children born in 1974 would have had only slightly less childhood paint lead exposure than those born in 1967, and this decrease in paint lead exposure may have been more than offset by a sharp increase in gasoline lead exposure.

The same pattern appears in Norway military tests for recruits around the age of 18 . Culturereduced and verbal-math tests in Norway showed gains of .63 and .58 IQ points per year, respectively, from 1954 to 1968 . These increases were followed by culture-reduced gains of .22 IQ points per year and verbal-math losses of .13 IQ points per year from 1968 to 1980 . The 1968 norm comparison (relative to 1954) compared young men born around 1950, when paint and gasoline lead exposure were low, with young men born around 1932, when paint lead exposure was very high. The 1980 norm comparison (relative to 1968) compared young men born around 1962, when gasoline lead exposure was higher, with young men born around 1950, when paint and gasoline lead exposure were very low. 


\section{Social Behavior Associated with IQ}

Although data on yearly changes in IQ are unavailable, temporal data are available for specific types of social behavior associated with lower IQ scores. Herrnstein and Murray, in their controversial book The Bell Curve, cite data showing that individuals with lower IQ levels account for a disproportionate share of violent crime and unwed births. Needleman and colleagues (1996) have also shown that higher bone lead levels are associated with an increase in aggressive and delinquent behavior among boys ages 7 to 10 with similar IQ levels.

Herrnstein and Murray associate IQ with social behavior based on data from the National Longitudinal Survey of Labor Market Experience of Youth (NLSY), a representative national sample of American youths. When the NLSY began in 1979, the 12,686 participants were ages 14 to 22 . In 1980, 94 percent of these youths were given the Armed Forces Qualification Test (AFQT). Herrnstein and Murray restated the raw scores on the AFQT in the IQ metric (a mean of 100 and a standard deviation of 15) and refer to these results as IQ scores. To justify the use of the AFQT as a measure of IQ, the authors show that this test has a very high correlation with other IQ tests available for some NLSY participants (Herrnstein and Murray).

Table 2 shows the average IQ (AFQT) levels of white males in the NLSY by their self-reported deepest involvement with the criminal justice system (Herrnstein and Murray). As an observed measure of criminal involvement, the NLSY data also reveal the percentage of white males who ever had an NLSY interview conducted in a correctional facility, by IQ percentiles, as shown in Table 3 (Herrnstein and Murray). In addition to the NLSY data, the authors cite research from Britain, Sweden, Denmark, and New Zealand, and conclude that the research as a whole indicates that incarcerated offenders have an average IQ of about 92 , eight points below the mean (Herrnstein and Murray). 
Table 2

NLSY White Male Self-Reported Deepest Involvement in Criminal Justice System

\begin{tabular}{|l|c|}
\hline \multicolumn{1}{|c|}{ Deepest Involvement in Criminal Justice System } & Average IQ \\
\hline Sentenced to a correctional facility & 93 \\
\hline Convicted but not incarcerated & 100 \\
\hline Booked but not convicted & 101 \\
\hline Stopped by the police but not booked & 103 \\
\hline No criminal justice system contact & 106 \\
\hline
\end{tabular}

Herrnstein and Murray

Table 3

Percent of NLSY White Males Interviewed in a Correctional Facility

\begin{tabular}{|l|c|}
\multicolumn{1}{|c|}{$\begin{array}{c}\text { PQ } \\
\text { Percentile Range }\end{array}$} & $\begin{array}{c}\text { Percent Interviewed in } \\
\text { Correctional Facility }\end{array}$ \\
\hline Lowest five percent & 12 \\
\hline${\text { Fifth to } 25^{\text {th }} \text { percentile }}_{25^{\text {th }} \text { to } 75^{\text {th }} \text { percentiles, }}$ & 7 \\
\hline Highest 25 percent & 0 \\
\hline
\end{tabular}

Herrnstein and Murray

By focusing exclusively on white males, the data in Tables 2 and 3 remove any confounding due to racial or gender bias relating to IQ tests and/or to law enforcement. Herrnstein and Murray also found that both self-reported and observed measures of criminality among white males were more strongly associated with IQ than with family socioeconomic status.

"In the case of the self-report data, higher socioeconomic status was associated with higher reported crime after controlling for IQ. In the case of incarceration, the role of socioeconomic background was close to nil after controlling for IQ, and statistically insignificant. By either measure of crime, a low IQ was a significant risk factor" (Herrnstein and Murray).

Herrnstein and Murray also examined confounding due to family demographics, by comparing white males from intact families "consisting of the biological mother and father" with white males from a "broken" home.

"Although family setting had an impact on crime, it did not explain away the predictive power of IQ. For example, a young man from a broken family and an average IQ and socioeconomic background had a 4 percent chance of having been interviewed in jail.

Switch his IQ to the $2 d$ centile, and the odds rise to 22 percent. (Switch his socioeconomic 
background to the $2 \mathrm{~d}$ centile instead, and the odds rise only from 4 to 5 percent.) The same conclusions apply to the measure of self-reported crime" (Herrnstein and Murray).

As shown in Table 4, Herrnstein and Murray also report a strong association between IQ and the incidence of unwed births among young white women in the NLSY.

Table 4

Unwed Births Among White Females in the NLSY

\begin{tabular}{|l|c|c|}
\hline \multicolumn{1}{|c|}{$\begin{array}{c}\text { IQ Percentile } \\
\text { Range }\end{array}$} & $\begin{array}{c}\text { Percent of White Females } \\
\text { That Have Unwed Births }\end{array}$ & $\begin{array}{c}\text { Percent of White Female First Births } \\
\text { That Are Unwed Births }\end{array}$ \\
\hline Lowest five percent & 32 & 42 \\
\hline Fifth to $25^{\text {th }}$ percentile & 17 & 23 \\
\hline $25^{\text {th }}$ to $75^{\text {th }}$ percentiles & 8 & 13 \\
\hline $75^{\text {th }}$ to $95^{\text {th }}$ percentiles & 4 & 7 \\
\hline Highest five percent & 2 & 7 \\
\hline
\end{tabular}

Herrnstein and Murray

Herrnstein and Murray found that socioeconomic status affects unwed birth rates, but did not explain the predictive power of IQ.

"Higher social status reduces the chances of an illegitimate first baby from about 19 percent for a woman who came from a very low status family to about 8 percent for a woman from a very high status family, given that the woman has average intelligence. Let us compare that 11 percentage point swing with the effect of an equivalent shift in intelligence (given average socioeconomic background). The odds of having an illegitimate first child drop from 34 percent for a [woman in the lowest 5 percent of IQ] to about 4 percent for a [woman in the highest 5 percent of IQ], a swing of 30 percentage points independent of any effect of socioeconomic status" (Herrnstein and Murray).

The role of family demographics was also found to have less influence than IQ on unwed births:

"Let us consider a white woman of average intelligence and average socioeconomic background. The odds that her first child would be born out of wedlock were:

10 percent if she was living with both biological parents.

18 percent if she was living with a biological parent and a stepparent. 
25 percent if she was living with her mother (with or without a live-in boyfriend). Consider the case of a young woman at risk, having lived with an unmarried biological mother at age 14. Given average socioeconomic background and an average IQ, the probability that her first baby would be born out of wedlock was 25 percent. If she had an IQ at the $98^{\text {th }}$ centile (an IQ of 130 or above), the probability plunged to 8 percent. If she had an IQ at the $2 \mathrm{~d}$ centile (an IQ of 70 or below), the probability soared to 55 percent. High socioeconomic status offered weak protection against illegitimacy once IQ had been taken into account."

Herrnstein and Murray caution that:

"Despite the relationship of low IQ to criminality, the great majority of people with low cognitive ability are law abiding."

They also state that

"the increase in crime over the past thirty years (like the increases in illegitimacy and welfare) cannot be attributed to changes in intelligence but rather must be blamed on other factors, which may have put people of low cognitive ability at greater risk than before."

It is certainly true that most people with low cognitive ability are law abiding, and most women with low cognitive ability do not become pregnant outside of marriage, but this does not mean that temporal changes in crime and unwed pregnancies are necessarily unrelated to changes in cognitive abilities. The NLSY data suggest that cognitive ability may affect an individual's foresight and comprehension of the long-term consequences of crime and unwed pregnancy. The important role of many other factors means that IQ is a dubious marker for any individual's propensity to commit violent crimes or become pregnant outside of marriage, but IQ may affect the rate at which any group of individuals will engage in such behavior. This distinction is 
illustrated in Table 5 by estimating the potential effect on violent crime per 100,000 population if the lowest three deciles of the IQ distribution each increased by six points.

Table 5

Illustration of Potential Effect on Crime Rates

Due to a Six Point Upward Shift in IQ for Lowest 30 Percent of the IQ Distribution

\begin{tabular}{|l|c|c|c|c|c|}
\hline \multicolumn{1}{|c|}{ IQ Decile } & Population & $\begin{array}{c}\text { Violent } \\
\text { Crimes }\end{array}$ & $\begin{array}{c}\text { Median } \\
\text { IQ }\end{array}$ & New IQ & $\begin{array}{c}\text { New Violent } \\
\text { Crimes }\end{array}$ \\
\hline First & 10,000 & 950 & 74 & 80 & 700 \\
\hline Second & 10,000 & 700 & 84 & 90 & 400 \\
\hline Third & 10,000 & 400 & 90 & 96 & 100 \\
\hline $4^{\text {th }}-8^{\text {th }}$ & 50,000 & 500 & 102 & 102 & 500 \\
\hline $9^{\text {th }}$ and $10^{\text {th }}$ & 20,000 & 0 & 122 & 122 & 0 \\
\hline Violent Crime per 100,000 Population & 2,550 & & & 1,700 \\
\hline
\end{tabular}

The second column of Table 5 shows the population distribution by IQ decile, assuming a total population of 100,000 . The third column shows the number of violent crimes by IQ decile if we assume (for the purpose of this illustration) that the percent of NLSY white males interviewed in jail is representative of the violent crime rate associated with different segments of the IQ distribution. For example, Table 3 showed that 12 percent of NLSY white males in the lowest five percent of IQ were interviewed in jail, and 7 percent of those in the $5^{\text {th }}$ to $25^{\text {th }}$ percentiles were interviewed in jail. Table 5 reflects an average of these percentages and shows that 9.5 percent of those in the lowest decile of IQ commit a violent crime. The next line shows that 7 percent of those in the second decile of IQ commit a violent crime. Table 3 also showed that 1 percent of NLSY white males in the $25^{\text {th }}$ to $75^{\text {th }}$ percentiles of IQ were interviewed in jail, so Table 5 reflects an average of 1 and 7 and shows that four percent of those in the third decile of IQ commit a violent crime. The last two columns of Table 5 show that a six-point increase in IQ could substantially reduce the number of violent crimes produced by each of the lowest three deciles of IQ, again based on the NLSY data in Table 3. Furthermore, the last row in Table 5 illustrates how this upward shift in the lowest three IQ deciles could reduce the overall crime rate per 100,000 population by about one third.

The choice of a six-point increase in IQ for the illustration in Table 5 was not arbitrary. Data from NHANES II and III show that the $75^{\text {th }}$ percentile for blood lead in young children fell from 24 to 
$9.5 \mathrm{ug} / \mathrm{dl}$ from 1976 through 1991 (Pirkle et al.). An almost identical decline, from 24 to $9.7 \mathrm{ug} / \mathrm{dl}$ was reported for the average blood lead of non-Hispanic black children from low-income families living in central cities with populations of 1 million or more (Pirkle et al.). Screening data from New York and Chicago show that blood lead for black children at age two in these cities began falling before the beginning of NHANES II, from about 36 to $24 \mathrm{ug} / \mathrm{dl}$ from 1970 through 1976 (US Environmental Protection Agency). Therefore, the blood lead levels of poor urban children in general may have declined by about $26 \mathrm{ug} / \mathrm{dl}$ from the peak use of gasoline lead in the early 1970s through the virtual elimination of lead in gasoline after 1987. At Schwartz's estimate of $.232 \mathrm{IQ}$ points lost per one ug/dl change in childhood blood lead above $15 \mathrm{ug} / \mathrm{dl}$, a drop of 26 $\mathrm{ug} / \mathrm{dl}$ in blood lead could increase IQ by six full points.

The change in the $75^{\text {th }}$ percentile of blood lead would likely affect the $25^{\text {th }}$ percentile of IQ more than other parts of the IQ distribution because of the inverse relationship between childhood blood lead and IQ, and because other variables that affect IQ are correlated with blood lead. Table 3 showed that NLSY white males below the $25^{\text {th }}$ percentile of cognitive ability (an IQ of 90) were about 7 times more likely to be interviewed in a correctional facility than white males in the $50^{\text {th }}$ percentile (an IQ of 100 ). Table 4 showed that NLSY white females below the $25^{\text {th }}$ percentile of IQ were about twice as likely to have unwed births as white females in the $50^{\text {th }}$ percentile. Therefore, an increase of six IQ points for those at or below the $25^{\text {th }}$ percentile of the IQ distribution could substantially affect the rate at which this subset of the population might engage in violent crime or become pregnant out of wedlock.

Throughout the last several decades, the social problems of violent crime and unwed pregnancies have been disproportionately associated with teenagers and young adults in poor urban areas. As explained above, average blood lead for poor children in urban areas probably began to rise as early as the 1940s, due to rising gasoline lead exposure combined with 
relatively little change in paint lead exposure from older housing. Therefore, temporal data on gasoline lead consumption might serve as a rough indicator for temporal changes in blood lead for poor urban children from 1940 to 1987 . If childhood lead exposure affects IQ, and IQ affects population rates for crime and unwed pregnancy, then changes in crime and unwed pregnancy rates from about 1960 to the late 1990s could reflect changes in IQ associated with temporal trends in gasoline lead consumption from 1940 through the early 1980s.

\section{DATA AND METHODS}

Norm comparisons for the Cognitive Abilities Test (Thorndike and Hagan) were examined to gauge the effects of the blood lead decline between NHANES II and III. The Cognitive Abilities Test (CogAT) has evolved over more than forty years with its predecessor, the Lorge-Thorndike Intelligence Tests. The CogAT is standardized jointly with the lowa Tests of Basic Skills ${ }^{\circledR}$ and the standardization sample is selected to represent the national student population with respect to ability and achievement, ethnic diversity and gender. Sample cells, including both public and nonpublic schools, are selected on the basis of school district size, region of the country, and socioeconomic characteristics, resulting in weighted student distributions that closely approximate the total national student population (Thorndike and Hagan).

The CogAT Multilevel Edition is given to children in grades 3 through 12. It includes verbal, quantitative, and nonverbal batteries, and reports norm comparisons for each of these three subscales. Each of these three batteries are made up of three separate tests:

- Verbal Battery: Verbal classification, sentence completion, and verbal analogies

- Quantitative Battery: Quantitative relations, number series, and equation building

- Nonverbal Battery: Figure classification, figure analogies, and figure analysis

The verbal and quantitative batteries require individuals to use verbal and quantitative concepts acquired from experience both in and out of school to solve verbal tasks and quantitative 
problems that have not been directly taught in school (Thorndike and Hagan). The nonverbal battery uses neither words nor numbers, and is more comparable to the culture-reduced tests for which Flynn has reported the higher rate of increase in IQ over time.

Norm comparisons are done when the CogAT is updated, establishing a new standard based on a new representative national sample of school age children. The CogAT Form 3 test was first used in 1977, the Form 4 update was introduced in 1984, and the Form 5 update was introduced in 1992. When the CogAT switched from Form 4 to Form 5 in 1992, both tests were administered to 3,119 students in 23 schools in 10 school districts, providing norm comparisons for the 1992 students relative to both the 1992 and the 1984 population standards.

"Lower scores on Form 5 indicate that the 1992 norm is 'easier' than the 1984-85 norm at that score level or that the age group on which the norms are based had higher ability in 1992 than in 1984-85" (Thorndike and Hagan, emphasis added).

In other words, if the same students in 1992 had higher scores relative to the old 1984 population norm, and lower scores relative to the new 1992 norm, then this indicates that the population cognitive ability increased between 1984 and 1992.

Average blood lead levels for children under six in the United States declined by 75 percent between NHANES II (1976-1980) and NHANES III Phase 1 (1988-1991) (Pirkle et al.). The nineand ten-year-olds taking the CogAT test in 1984 would have been under age six during the NHANES II period. The nine- and ten-year-olds taking the CogAT test in 1992 would have been under age six in the years during and just prior to the NHANES III Phase 1 survey period. This analysis compares the decline in childhood blood lead between NHANES II and III with the 1992 CogAT norm comparisons (relative to 1984) for children ages 9 and 10, in order to assess whether any increase in IQ levels is consistent with estimates of the IQ to blood lead relationship. 
The 1992 CogAT norm comparison for children ages 12 to 16 , and the 1984 norm comparison (relative to 1977) for children ages 9 to 16 are also examined to determine whether long-term IQ gains reported by Flynn are evident across all age groups and both time periods. The analysis also considers whether any deviations from the Flynn trend might be explained by variations in childhood lead exposure.

\section{Regression Analyses}

All of the regression analyses described below compare temporal changes in lead exposure rates with subsequent changes in population rates for crime and unwed pregnancies. For each regression analysis, the lag (number of years between lead exposure and associated change in crime and unwed pregnancy) with the best regression "fit" (highest $\mathrm{R}^{2}$ and lowest $\mathrm{p}$-value for lead) is compared with the median and mode age of violent criminals and women who have unwed pregnancies. If IQ losses are associated with lead exposure in the first years of life, and if crime and unwed pregnancy are associated with IQ, then the best-fit lag for each regression should be approximately equal to the median and mode age criminals and women with unwed pregnancies.

It should be noted that the best-fit lags for gasoline lead exposure relative to unwed pregnancy and crime should include a lag of about one year from the time of tetraethyl lead consumption by refineries to the age when childhood blood lead would be most affected. The average time for refinery storage, gasoline refining, and shipment to gasoline stations was approximately six months from the time when tetraethyl lead was "consumed" (purchased) by refineries until it was available for retail sale in gasoline. During the years when lead was used extensively in gasoline, blood lead levels were also most highly correlated with gasoline lead consumption in the previous two months (Schwartz and Pitcher). Also, the median and mode ages for unwed pregnancy and violent crime arrests will, on average, reflect data for each age category plus six 
months. For example, unwed pregnancies for women age 19 will include a distribution of women from one day after their $19^{\text {th }}$ birthday to one day before their $20^{\text {th }}$ birthday. Therefore, a best-fit lag of 20 years for unwed pregnancies to women age 19 would be consistent with lead exposure during the first year of life.

\section{Gasoline Lead Exposure}

Data on annual US consumption of lead in gasoline from 1941 through 1987 were obtained from the US Geological Survey. As discussed below, these gasoline lead data were used in regression analyses of subsequent trends in violent crime rates and unwed pregnancy rates. Both of these dependent variables are measured in terms of population rates (e.g., violent crime per 100,000 population). Therefore, annual consumption of lead in gasoline (tons of tetraethyl lead consumed by refiners) was divided by total population (for the same year) to estimate temporal changes in population lead exposure rates, as a proxy for temporal changes in blood lead levels. Dividing tons of lead consumed each year by total population for the same year accounts for the growth and geographic dispersion of the national population between 1941 and 1987, which would reduce the lead exposure per person associated with any given level of total lead consumption in gasoline.

\section{Violent Crime}

Multiple regression analysis was used to assess the relationship between changes in gasoline lead exposure and changes in violent crimes per 100,000 population, based on the crime rates for murder, rape, robbery, aggravated assault, and all violent crime reported in each year from 1960 through 1998 (US Department of Justice). Lags of 15 to 28 years were tested for gasoline lead exposure (consumption per thousand population) and the best fit lag structure (highest $\mathrm{R}^{2}$ and lowest $\mathrm{p}$-value for lead) was compared with the median and mode age of those arrested for each category of violent crime. The national unemployment rate, the percentage of the 
population in high-crime age brackets (ages 15-19, and 20-24), and the teen unemployment rate (ages 15-19) were tested as covariates (US Bureau of Labor Statistics; US Department of Commerce).

Comparing the best fit lag structure for reported crime with the age of those arrested assumes that the age distribution for violent crime arrests is representative of the age distribution for all reported crime, where total arrests over this time period account for about one-third of all violent crimes reported. Median and mode ages for all violent crime are heavily weighted by robbery and aggravated assault, which account for 38 percent and 54 percent of violent crime, respectively.

\section{Gasoline and White Lead Exposure and Long Term Trends in the Murder Rate}

Regression analysis was also used to assess the relationship between changes in gasoline and white lead (in paint) exposure from 1876 through 1987 and subsequent changes in the murder rate from 1900 to 1998 (National Centers for Health Statistics). Lags of 15 to 28 years were tested for lead exposure (consumption per thousand population) and the best fit lag structure was compared with the median and mode age of those arrested for murder between 1960 and 1997. The unemployment rate was also tested as a covariate in this regression.

White lead data for 1914 through 1978 were available from the US Geological Survey. For 1876 through 1913 the consumption of white lead in paint was estimated as a percentage of total refined lead production. Table 6 shows that white lead consumption accounted for 29.4 percent of refined lead production in 1914, and accounted for about 29 percent of refined lead production in 1915, 1919, and 1921. White lead accounted for a much smaller share of refined lead in 1917 and 1918, but housing starts were also much lower in these two years. After 1921, the white lead share of refined lead use declined as other industrial applications for lead were expanding. 
Therefore, this analysis assumes that white lead consumption accounted for approximately 29.4 percent of refined lead production in years prior to 1914. As a second check for this assumption, Table 6 also shows available data on consumption of paint made from white lead in oil (Mattiello) and shows the tons of white lead consumed per million gallons of white lead paint. This ratio falls between .61 and .86 for years with reported data on white lead and white lead paint consumption. The estimated white lead consumption per reported white lead paint consumption in 1909 and 1904 are within this range, and the ratio for 1899 is just above this range.

Table 6

Estimates for White Lead in Paint before 1914

\begin{tabular}{|c|c|c|c|c|c|}
\hline & $\begin{array}{c}\text { White } \\
\text { Lead }^{*}\end{array}$ & $\begin{array}{c}\text { Refined } \\
\text { Lead }^{*}\end{array}$ & $\begin{array}{c}\text { White Lead } \\
\text { \% of Refined }\end{array}$ & $\begin{array}{c}\text { Paint from White Lead } \\
\text { in Oil (MM Gallons) }\end{array}$ & $\begin{array}{c}\text { White Lead Tons } \\
\text { per Million Gallons }\end{array}$ \\
\hline 1899 & $88(\mathrm{E})$ & 298 & $29.4 \%(\mathrm{E})$ & 8.1 & $1.08(\mathrm{E})$ \\
\hline 1904 & $116(\mathrm{E})$ & 393 & $29.4 \%(\mathrm{E})$ & 15.6 & $0.74(\mathrm{E})$ \\
\hline 1909 & $131(\mathrm{E})$ & 447 & $29.4 \%(\mathrm{E})$ & 16.8 & $0.78(\mathrm{E})$ \\
\hline 1914 & 159 & 542 & $29.4 \%$ & 19.1 & 0.83 \\
\hline 1915 & 156 & 550 & $28.4 \%$ & $\mathrm{NA}$ & $\mathrm{NA}$ \\
\hline 1916 & 129 & 571 & $22.6 \%$ & $\mathrm{NA}$ & $\mathrm{NA}$ \\
\hline 1917 & 115 & 611 & $18.9 \%$ & $\mathrm{NA}$ & $\mathrm{NA}$ \\
\hline 1918 & 103 & 640 & $16.1 \%$ & $\mathrm{NA}$ & 0.86 \\
\hline 1919 & 139 & 482 & $28.8 \%$ & 16.1 & 0.61 \\
\hline 1921 & 136 & 449 & $30.3 \%$ & 22.4 & 0.70 \\
\hline 1923 & 130 & 618 & $21.0 \%$ & 18.5 & 0.74 \\
\hline 1925 & 131 & 767 & $17.1 \%$ & 17.7 & \\
\hline
\end{tabular}

*US Geological Survey; ** Mattiello

\section{Teenage Abortions and Unwed Births}

The disproportionate concentration of unwed mothers in the bottom 20 percent of the NLSY suggests that temporal trends in unwed pregnancy may reflect trends in cognitive ability. The time period associated with gasoline lead exposure, however, includes data from the 1950s, long before the Roe $\mathrm{v}$. Wade decision in 1973 made abortion widely available. This analysis assumes that any cognitive deficiency associated with unwed pregnancy is associated with conception and not with the decision to carry a child to term. Therefore, the analysis combines data on abortion rates and unwed birth rates to create trend data for unwed pregnancies. Multiple regression analysis was used to assess the relationship between changes in gasoline lead and subsequent changes in unwed pregnancies. 
Abortion rate data were available for women ages 20-24, 18-19, and 15-17, for 1972 through 1996 (Alan Guttmacher Institute). For 1969 through 1971, data on abortion rates for all women were used to estimate the rates for these specific age brackets (Koonin et al.). The analysis reflects only unwed birth data for years prior to 1969 because no reliable data are available for abortions in these years. Data on unwed birth rates were available for each age bracket over age 15 for 1955 through 1997 (Centers for Disease Control and Prevention, 1995 and June 1998).

The abortion rate for each year was added to the unwed birth rate for the following year to create the unwed pregnancy rate for each age bracket. The one-year lag for births recognizes that most abortions are in the first trimester while gestation to birth is nine months. Combining abortion and birth rates in this analysis also partially controls for the potentially important confounding variable of changes in abortion law.

The abortion rate data report the number of abortions per thousand women in each age bracket, whereas the unwed birth rate data report unwed births per thousand unmarried women in each age bracket. This analysis simply adds the two rates together, because the abortion rate data for unmarried women in specific age brackets were not available. The abortion rate data are only a factor in years after 1968, however, and only a significant factor in years after 1973, when the married percentage of young women was already quite low. In 1970, only four percent of females age 15-17 and 22 percent of females age 18-19 were married. By 1979, only 16 percent of women age 18-19 were married. Therefore, abortion rates per 1000 teenage females should also approximate the abortion rate for unmarried teenagers. The abortion rate for women in the 20-24 age bracket will understate the abortion rate for unmarried women in this age bracket, particularly in the first few years after Roe v. Wade when a large percentage of women in their 
early twenties were married. The percent of never-married women ages 20-24 rose from 36 percent in 1970 to 50 percent in 1980 to 67 percent in 1993 (US Dept of Health and Human Services), but married females (of all ages) account for only about 22 percent of all abortions (Centers for Disease Control and Prevention).

Lags of 12 to 24 years were tested for gasoline lead per thousand population and the best fit lag structure was compared with the median and mode age of unwed pregnancies in each age bracket. The regression analysis of these data also includes a dummy variable for years after the Roe v. Wade decision.

Abortion rate and birth rate data were also available for girls under the age of 15 for 1972 through 1997, where the population denominator used to calculate each rate is the number of girls age 14 (Alan Guttmacher Institute). Other sources provide unwed birth rates for girls under 15 where the population denominator is the number of girls ages $10-14$. This denominator provides relatively little birth rate variation to support a regression analysis, and may obscure trends in the age 14 population likely to dominate the under 15 abortion and birth rate data. Also, only a very small percent of girls under age 15 were married after 1972 . Therefore, the regression analysis for girls under age 15 uses the overall birth and abortion rates for this age bracket from 1972 through 1997, without any dummy variable for Roe v. Wade.

\section{Covariates}

The dependent variables in this analysis are measured as population rates (crime and unwed pregnancy rates) or in other relative terms (IQ relative to population standards), as are the lead exposure variables (gasoline and paint lead per thousand population). Therefore, potential covariates are also measured in relative terms, as trends in population percentages. 
To evaluate potentially confounding factors affecting CogAT IQ norm comparisons, available data were collected on temporal trends in maternal education levels, economic status, and family demographics. Temporal trend data were available for the percentage of mothers with less than 12 years or more than 16 years education. Trends in economic status were measured by the percentage of children living below the poverty level and below 200 percent of the poverty level. Trends in family demographics were measured by the percentage of children living with their mothers only. As noted above, the regression analyses for violent crime were also tested with dummy variables for the teen and/or overall unemployment rate and the percentage of the population in younger age brackets associated with crime.

\section{RESULTS}

Table 7 shows the change in each quartile of the blood lead distribution between NHANES II and NHANES III Phase 1 for children under age six, and the estimated change in IQ that would result from published estimates of the IQ to blood lead slope. The $13.1 \mathrm{ug} / \mathrm{dl}$ decline in the $25^{\text {th }}$ percentile of childhood blood lead would result in an increase of $3.04 \mathrm{IQ}$ points based on the slope estimate by Schwartz (.232) for blood lead above $15 \mathrm{ug} / \mathrm{dl}$. The $11.3 \mathrm{ug} / \mathrm{dl}$ decline in median blood lead would result in an increase of 3.65 IQ points at the slope estimate by Schwartz (.323) for blood lead below $15 \mathrm{ug} / \mathrm{dl}$. The $9.8 \mathrm{ug} / \mathrm{dl}$ decline in the $25^{\text {th }}$ percentile would increase IQ by 3.17 points at the Schwartz slope estimate (.323), and would increase IQ by 5.19 points at the slope estimate reported by Dudek and Merecz (.53) for blood lead at $10 \mathrm{ug} / \mathrm{dl}$.

Table 7

Expected IQ Change due to Blood Lead Decline between NHANES II and III

\begin{tabular}{|l|c|c|c|c|c|}
\hline & $\begin{array}{c}\text { NHANES II } \\
(1976-80)^{1}\end{array}$ & $\begin{array}{c}\text { NHANES III Phase 1 } \\
(1988-91)^{1}\end{array}$ & $\begin{array}{c}\text { Change } \\
(\text { ug/dL) }\end{array}$ & $\begin{array}{c}\text { IQ points } \\
\text { per ug/dL }\end{array}$ & $\begin{array}{c}\text { Expected } \\
\text { IQ change }\end{array}$ \\
\hline $25^{\text {th }}$ Percentile & 12.0 & 2.2 & 9.8 & $.323^{2}$ & 3.17 \\
& & & $.530^{3}$ & 5.19 \\
\hline Median & 15.0 & 3.7 & 11.3 & $.323^{2}$ & 3.65 \\
\hline $75^{\text {th }}$ Percentile & 19.0 & 5.9 & 13.1 & $.232^{2}$ & 3.04 \\
\hline
\end{tabular}

1. Pirkle et al.

2. Schwartz

3. Dudek and Merecz 
Table 8 compares the predicted change in IQ (from Table 7) with the 1992 CogAT norm comparisons (relative to 1984) for 9 and 10 year olds with 1992 Standard Age Scores (SAS) of $110\left(25^{\text {th }}\right.$ percentile), 100 (median), and $90\left(75^{\text {th }}\right.$ percentile). Children ages 9 and 10 at each of these quartiles of the 1992 distribution scored substantially higher against the 1984 norm. Table 9, however, shows that the 1992 norm comparison found little change in IQ for children ages 12 and 13, and children ages 15 and 16 had substantially lower scores against the 1984 norm. Table 10 shows the annual rate of change in CogAT subscale and composite IQ scores for different age groups, for both the 1992 norm comparison (relative to 1984) and the 1984 norm comparison (relative to 1977).

\section{Table 8}

Actual CogAT IQ Change versus Expected IQ Change from Blood Lead Decline

\begin{tabular}{|c|c|c|c|c|c|}
\hline \multirow{2}{*}{$\begin{array}{c}\text { Form } 5 \text { SAS } \\
(1992)\end{array}$} & \multicolumn{2}{|c|}{ Form 4 SAS (1984) } & \multicolumn{2}{|c|}{ CogAT IQ Change } & \multirow{2}{*}{$\begin{array}{l}\text { Expected } \\
\text { IQ Change }\end{array}$} \\
\hline & 9 year olds & 10 year olds & 9 year olds & 10 year olds & \\
\hline $110 \quad\left(75^{\text {th }}\right.$ percentile $)$ & 115.7 & 116.7 & 5.7 & 6.7 & $3.17-5.19$ \\
\hline 100 (median) & 104.0 & 105.3 & 4.0 & 5.3 & 3.65 \\
\hline $90 \quad\left(25^{\text {th }}\right.$ percentile $)$ & 93.0 & 93.0 & 3.0 & 3.0 & 3.04 \\
\hline
\end{tabular}

Thorndike and Hagan.

\section{Table 9}

1984 to 1992 Change in CogAT IQ by Age and Quartile

\begin{tabular}{|c|c|c|c|c|c|c|}
\hline $\begin{array}{c}\text { Form } 5 \text { SAS (1992) } \\
\text { (sample size) }\end{array}$ & $\begin{array}{l}\text { Age } 9 \\
(852)\end{array}$ & $\begin{array}{l}\text { Age } 10 \\
(459)\end{array}$ & $\begin{array}{c}\text { Age } 12 \\
(978)\end{array}$ & $\begin{array}{c}\text { Age } 13 \\
(474)\end{array}$ & $\begin{array}{l}\text { Age } 15 \\
(222)\end{array}$ & $\begin{array}{l}\text { Age 16 } \\
(134)\end{array}$ \\
\hline $110 \quad\left(75^{\text {th }}\right.$ percentile $)$ & 5.7 & 6.7 & 2.0 & 2.0 & -1.3 & -2.7 \\
\hline 100 (median) & 4.0 & 5.3 & 0.7 & 0.7 & -2.3 & -3.3 \\
\hline $90 \quad\left(25^{\text {th }}\right.$ percentile $)$ & 3.0 & 3.0 & 0.3 & -0.3 & -2.7 & -2.3 \\
\hline
\end{tabular}

Thorndike and Hagan.

Table 10

Annual Rate of Change in Median CogAT Sub-Scale and Composite IQ Scores

\begin{tabular}{|l|c|c|c|c|c|c|}
\hline $\begin{array}{c}\text { 1884 Norm Comparison } \\
\text { (sample size) }\end{array}$ & $\begin{array}{c}\text { Age 9 } \\
(318)\end{array}$ & $\begin{array}{c}\text { Age 10 } \\
(476)\end{array}$ & $\begin{array}{c}\text { Age 12 } \\
(282)\end{array}$ & $\begin{array}{c}\text { Age 13 } \\
(614)\end{array}$ & $\begin{array}{c}\text { Age 15 } \\
(280)\end{array}$ & $\begin{array}{c}\text { Age 16 } \\
(218)\end{array}$ \\
\hline 1977-84 Verbal & 0.00 & 0.00 & 0.00 & 0.00 & 0.00 & 0.14 \\
\hline 1977-84 Quantitative & -0.14 & 0.00 & 0.14 & 0.29 & 0.29 & 0.14 \\
\hline 1977-84 Non-Verbal & 0.29 & 0.43 & 0.43 & 0.14 & -0.14 & -0.14 \\
\hline 1977-84 Composite IQ & 0.05 & 0.14 & 0.19 & 0.14 & 0.05 & 0.05 \\
\hline 1892 Norm Comparison \\
\hline \multicolumn{7}{|l|l|l|l|}{} \\
\hline 1984-92 Verbal & 0.63 & 0.63 & -0.13 & 0.00 & -0.38 & -0.38 \\
\hline 1984-92 Quantitative & 0.38 & 0.63 & 0.13 & 0.13 & 0.00 & -0.38 \\
\hline 1984-92 Non-Verbal & 0.50 & 0.75 & 0.25 & 0.13 & -0.50 & -0.50 \\
\hline 1984-92 Composite IQ & 0.50 & 0.67 & 0.08 & 0.08 & -0.29 & -0.42 \\
\hline
\end{tabular}

Thorndike and Hagan.

Figure 2 presents temporal trend data for confounding variables that might have affected the changes in CogAT IQ between 1977 and 1992. The percentage of children living with mothers 
only and the percentage of children living in poverty both increased from 1970 to 1990, and there was no significant change in the percentage of children living below 200 percent of the poverty level. The percentage of mother's with less than 12 years of education declined between 1970 and 1990 , and the percentage of mothers with more than 16 years of education increased.

US Department of Health and Human Services: Trends in the Well-Being of America's Children and Youth: 1996

US Department of Health and Human Services: Health, United States, 1995.

\section{Violent Crime and Unwed Teen Pregnancy}

Table 11 shows the regression results for the best fit lag structures associating lead exposure with unwed pregnancy and violent crime. Table 12 compares the best-fit lag structure (highest $R^{2}$ and lowest $p$-value for lead) for each of these regressions with the median and mode ages of unwed pregnant teens in each age bracket and individuals arrested in each violent crime category. Figures 3 through 12 show a time series comparison of lead exposure per thousand population versus the best-fit lags for each of the unwed pregnancy and violent crime categories.

\section{Table 11}

\section{Regression Results for Unwed Pregnancy and Violent Crime}

\begin{tabular}{|c|c|c|c|c|c|}
\hline \multicolumn{5}{|c|}{$\begin{array}{c}\text { Figure } 2 \\
\text { Temporal Trends in IQ Covariates }(26,27)\end{array}$} & \\
\hline & 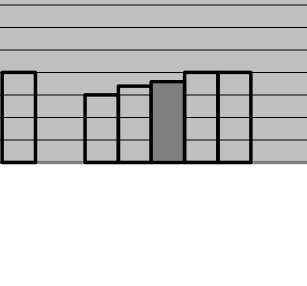 & Q & $\mathbb{N}$ & $\begin{array}{l}\mathbf{\Delta} 1970 \\
\mathbf{\square} 1975 \\
\mathbf{\square} 1980 \\
\mathbf{\square} 1985 \\
\mathbf{\square} 1990\end{array}$ & \\
\hline $\begin{array}{c}\text { Dependent } \\
\text { Variable }\end{array}$ & $\begin{array}{c}\text { Independent } \\
\text { Variable }\end{array}$ & Coefficient & $\begin{array}{l}\text { Standard } \\
\text { Error }\end{array}$ & p-Value & $\mathbf{R}^{2}$ \\
\hline \multirow{2}{*}{$\begin{array}{l}\text { Teen Pregnancy } \\
\text { Under Age } 15\end{array}$} & Intercept & 8.45 & 0.97 & .0000 & \multirow[b]{2}{*}{.58} \\
\hline & Lead, 15-year lag & 4.97 & 0.89 & .0000 & \\
\hline \multirow{3}{*}{$\begin{array}{l}\text { Unwed Pregnancy } \\
\text { Ages } 15-17\end{array}$} & Intercept & -1.01 & 2.30 & .6634 & \multirow{3}{*}{.96} \\
\hline & Lead, 17-year lag & 26.28 & 2.99 & .0000 & \\
\hline & Roe v. Wade & 22.78 & 1.76 & .0000 & \\
\hline Unwed Pregnancy & Intercept & -1.97 & 5.93 & .7417 & \\
\hline
\end{tabular}




\begin{tabular}{|c|c|c|c|c|c|}
\hline \multirow[t]{2}{*}{ Ages 18-19 } & Lead, 20-year lag & 60.99 & 8.63 & .0000 & \multirow[t]{2}{*}{.94} \\
\hline & Roe v. Wade & 38.86 & 5.39 & .0000 & \\
\hline \multirow{2}{*}{$\begin{array}{l}\text { Unwed Pregnancy } \\
\text { Ages } 20-24\end{array}$} & Intercept & -2.37 & 5.68 & .6793 & \multirow[b]{2}{*}{.90} \\
\hline & Lead, 24-year lag & 96.14 & 5.88 & .0000 & \\
\hline \multirow{2}{*}{$\begin{array}{l}\text { Murder } \\
(1960-1998)\end{array}$} & Intercept & 3.40 & 0.62 & .0000 & \multirow[b]{2}{*}{.60} \\
\hline & Lead, 18-year lag & 4.74 & 0.62 & .0000 & \\
\hline \multirow{2}{*}{$\begin{array}{l}\text { Murder } \\
(1900-1998)\end{array}$} & Intercept & 527.81 & 725.13 & .7279 & \multirow[b]{2}{*}{.46} \\
\hline & Lead, 21-year lag & 5.98 & 0.66 & .0000 & \\
\hline \multirow[b]{2}{*}{ Assault } & Intercept & -24.08 & 19.00 & .2139 & \multirow[b]{2}{*}{.89} \\
\hline & Lead, 23-year lag & 327.41 & 19.29 & .0000 & \\
\hline \multirow{3}{*}{ Rape } & Intercept & -9.73 & 4.32 & .0306 & \multirow{3}{*}{.87} \\
\hline & Lead, 21-year lag & 29.90 & 2.33 & .0000 & \\
\hline & Teen Unemployment & 0.63 & 0.28 & .0316 & \\
\hline \multirow{3}{*}{ Robbery } & Intercept & -62.41 & 33.95 & .0742 & \multirow{3}{*}{.79} \\
\hline & Lead, 19-year lag & 181.36 & 19.31 & .0000 & \\
\hline & Teen Unemployment & 4.45 & 2.30 & .0603 & \\
\hline \multirow{3}{*}{$\begin{array}{l}\text { All Violent } \\
\text { Crime }\end{array}$} & Intercept & -581.42 & 600.04 & .3398 & \multirow{3}{*}{.90} \\
\hline & Lead, 23-year lag & 4683.36 & 324.21 & .0000 & \\
\hline & Teen Unemployment & 81.15 & 39.03 & .0457 & \\
\hline
\end{tabular}

Table 12

Comparison of Best-Fit Lags with Median and Mode Ages of Affected Populations

\begin{tabular}{|l|c|c|c|}
\hline \multirow{2}{*}{ Dependent Variable } & Best-Fit & \multicolumn{2}{c|}{ Age of Unwed Women and Arrests } \\
\cline { 3 - 4 } & & Mode & Median \\
\hline Teen Pregnancy under Age 15 & 15 & 14 & 14 \\
\hline Unwed Pregnancy Ages 15-17 & 17 & 17 & 17 \\
\hline Unwed Pregnancy Ages 18-19 & 20 & 19 & 19 \\
\hline Unwed Pregnancy Ages 20-24 & 24 & $21-23$ & $21-23$ \\
\hline Murder (1960-98) & 18 & $18-23$ & $23-29$ \\
\hline Murder (1900-98) & 21 & $18-23$ & $23-29$ \\
\hline Assault & 23 & $18-24$ & $25-28$ \\
\hline Rape & 21 & $18-21$ & $22-27$ \\
\hline Robbery & 19 & $17-18$ & $19-22$ \\
\hline All Violent Crime & 23 & $18-21$ & $22-26$ \\
\hline
\end{tabular}

${ }^{*}$ Ranges shown for arrests reflect medians and modes in 1965, 70, 75, 80, 85, 90, and 1995. 

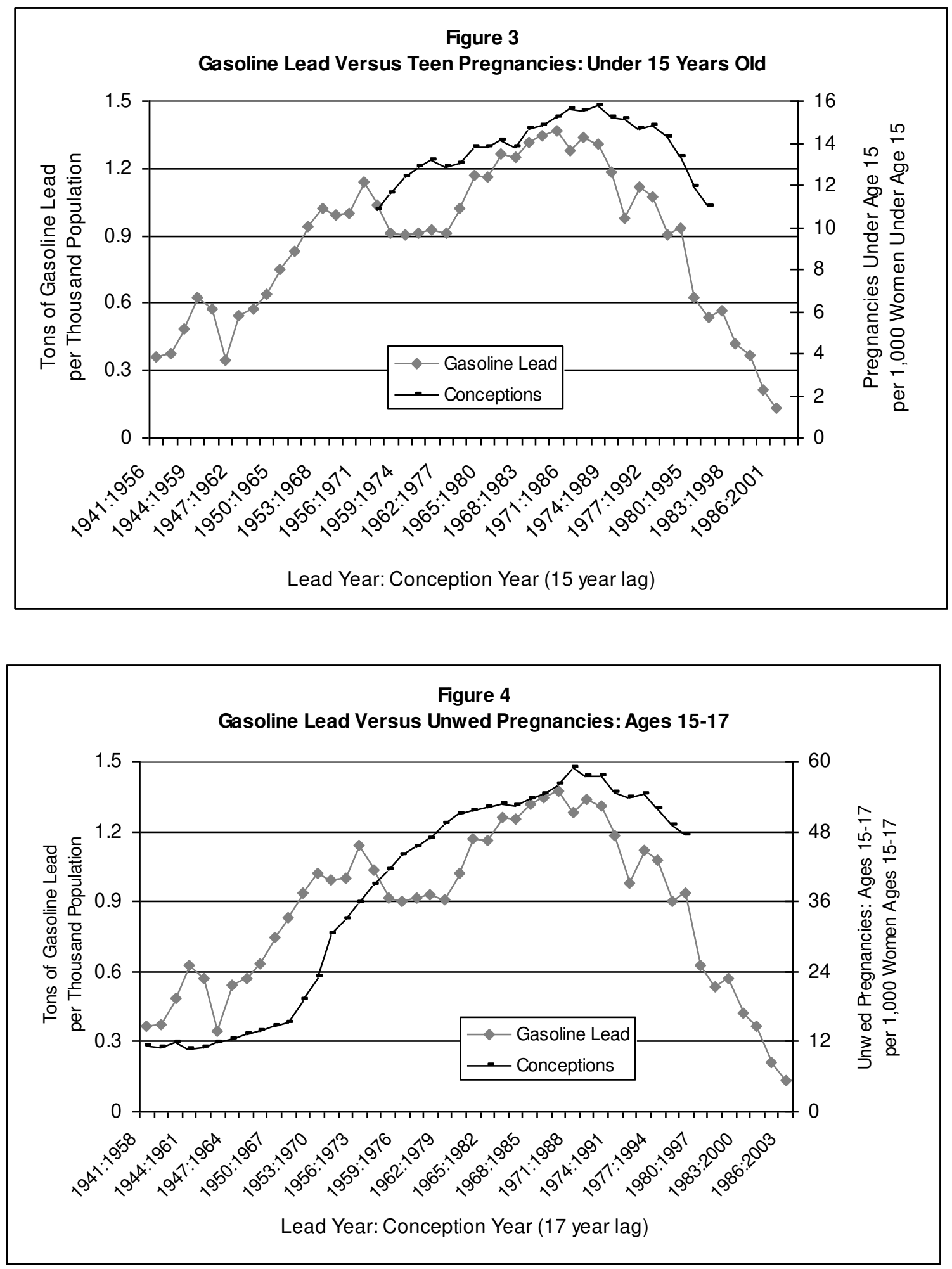
Figure 5

Gasoline Lead Versus Unwed Pregnancies: Ages 18-19

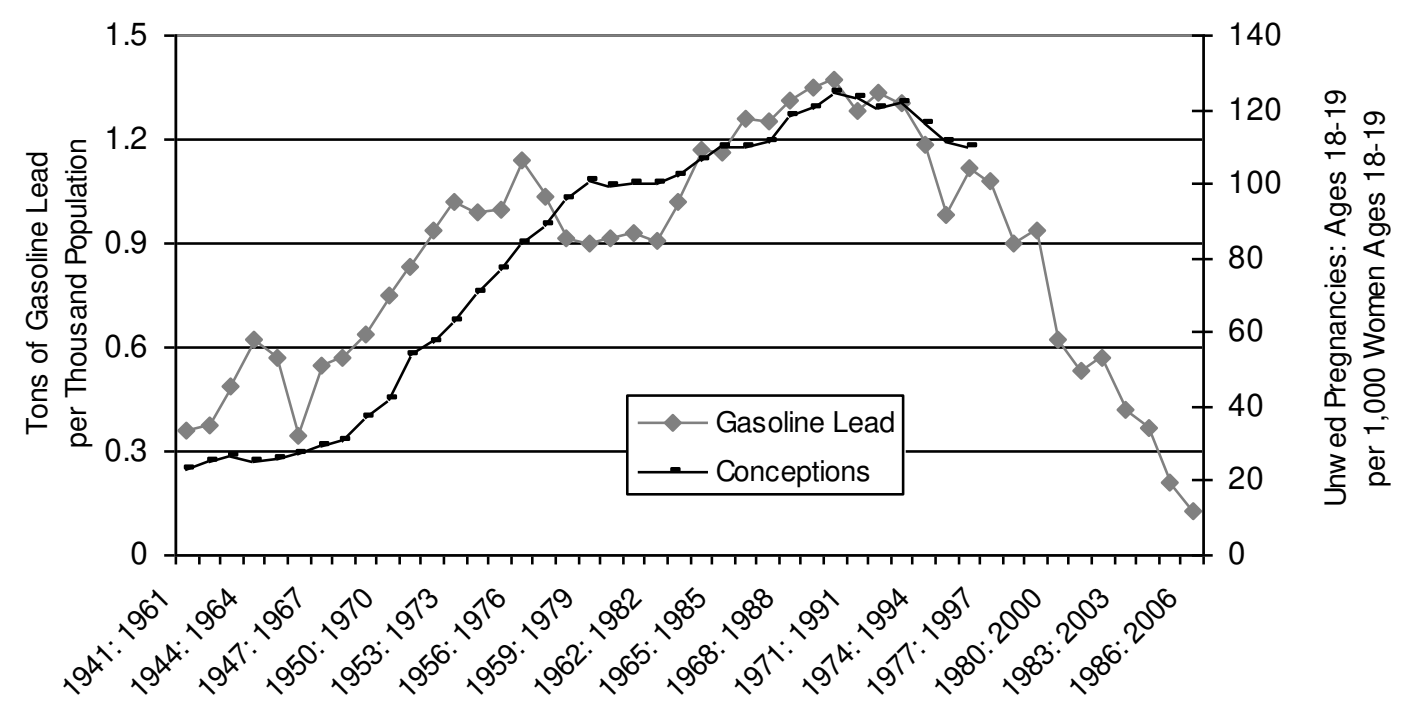

Lead Year: Conception Year (20 year lag) 
Figure 6

Gasoline Lead Versus Unwed Pregnancies: Ages 20-24

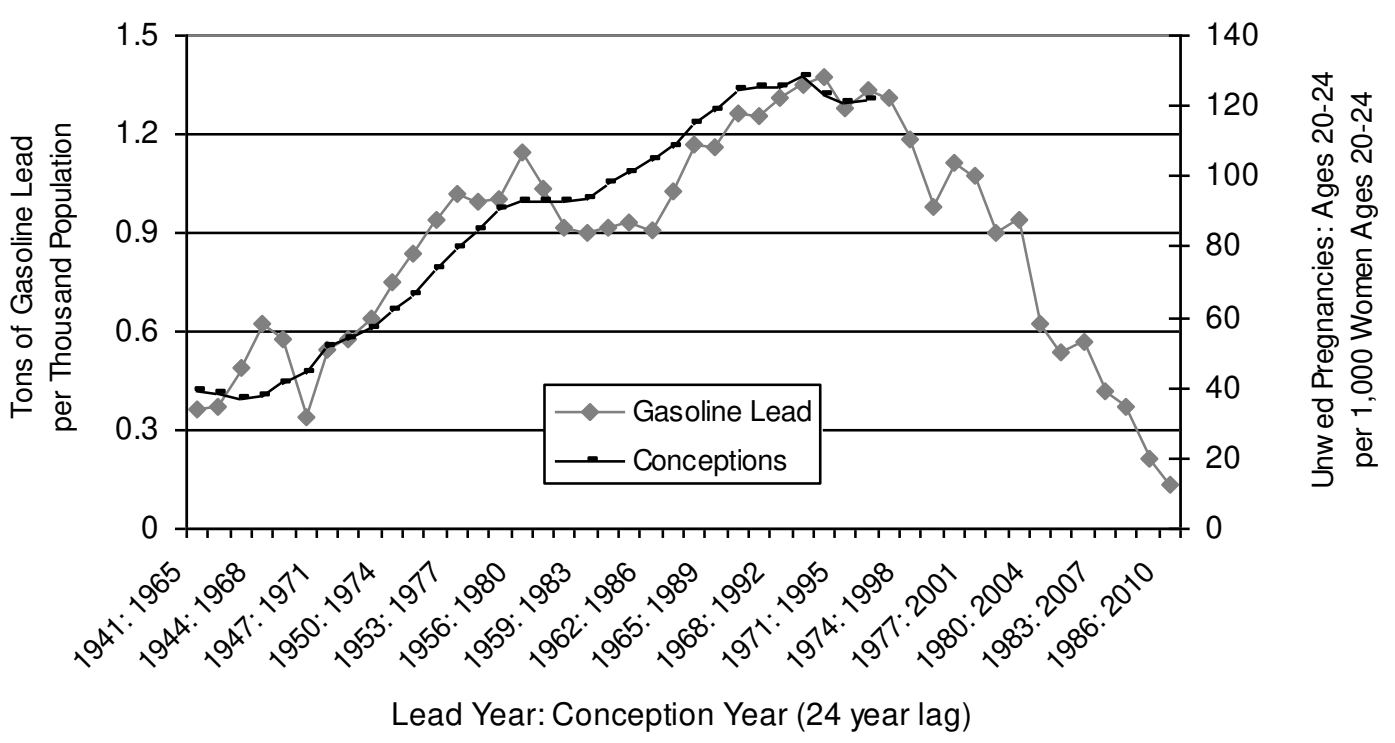

Figure 7

Gasoline Lead Versus Rape

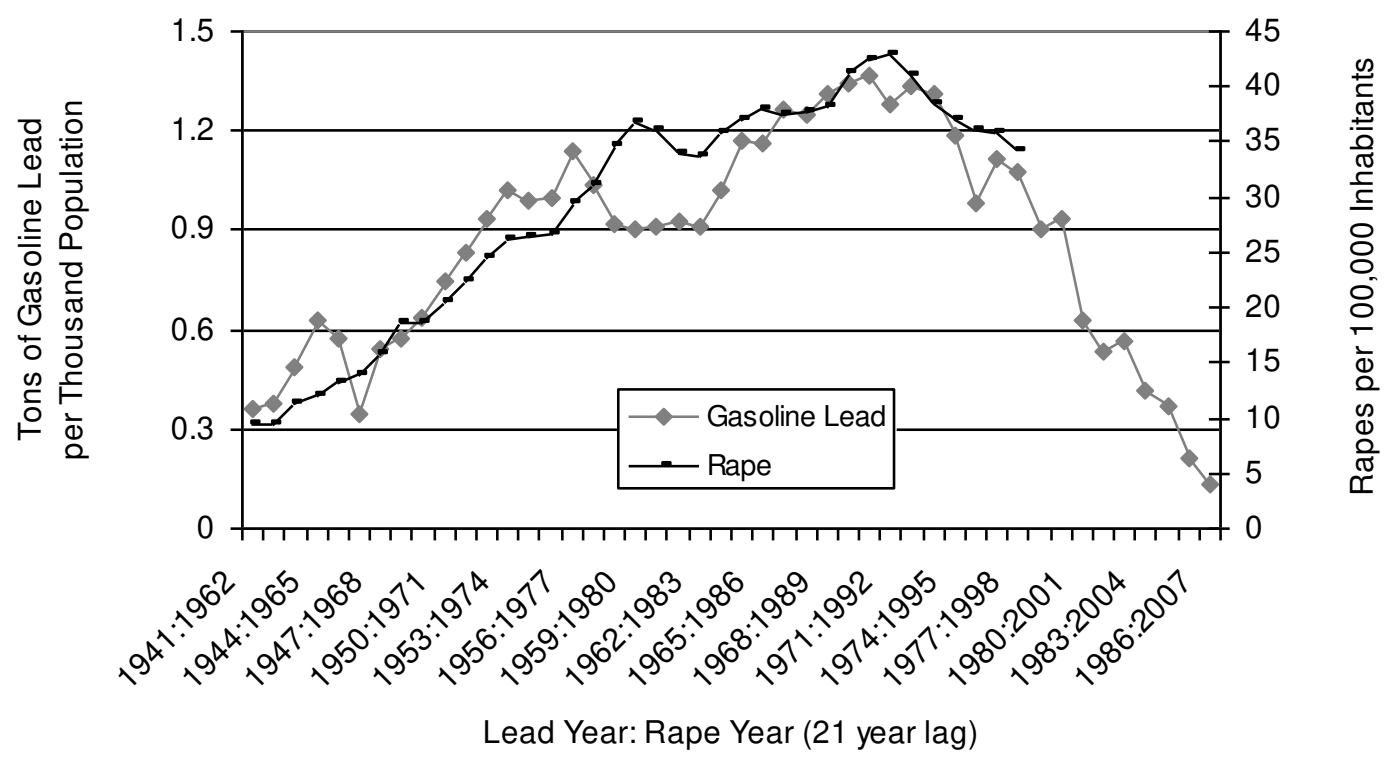



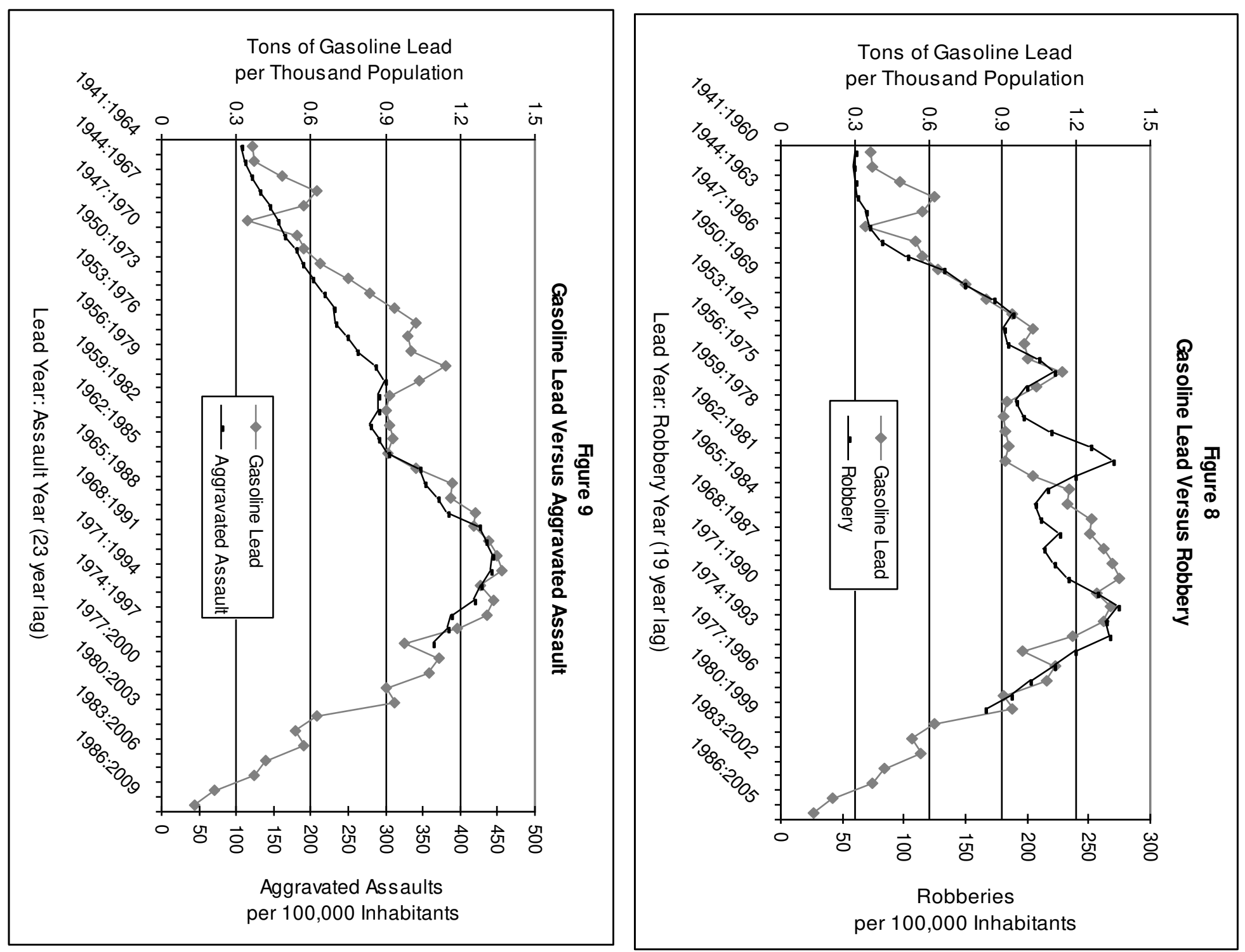


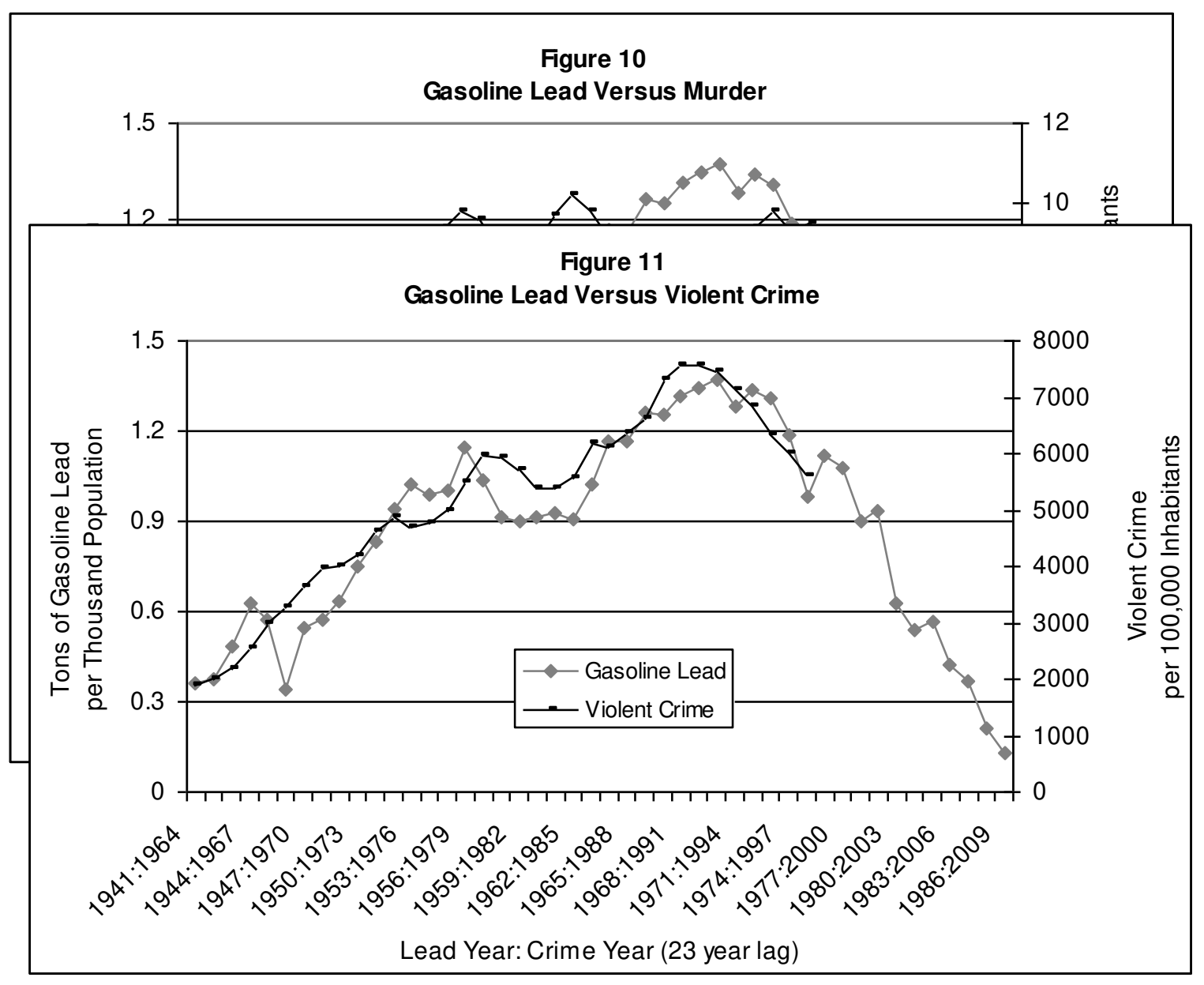




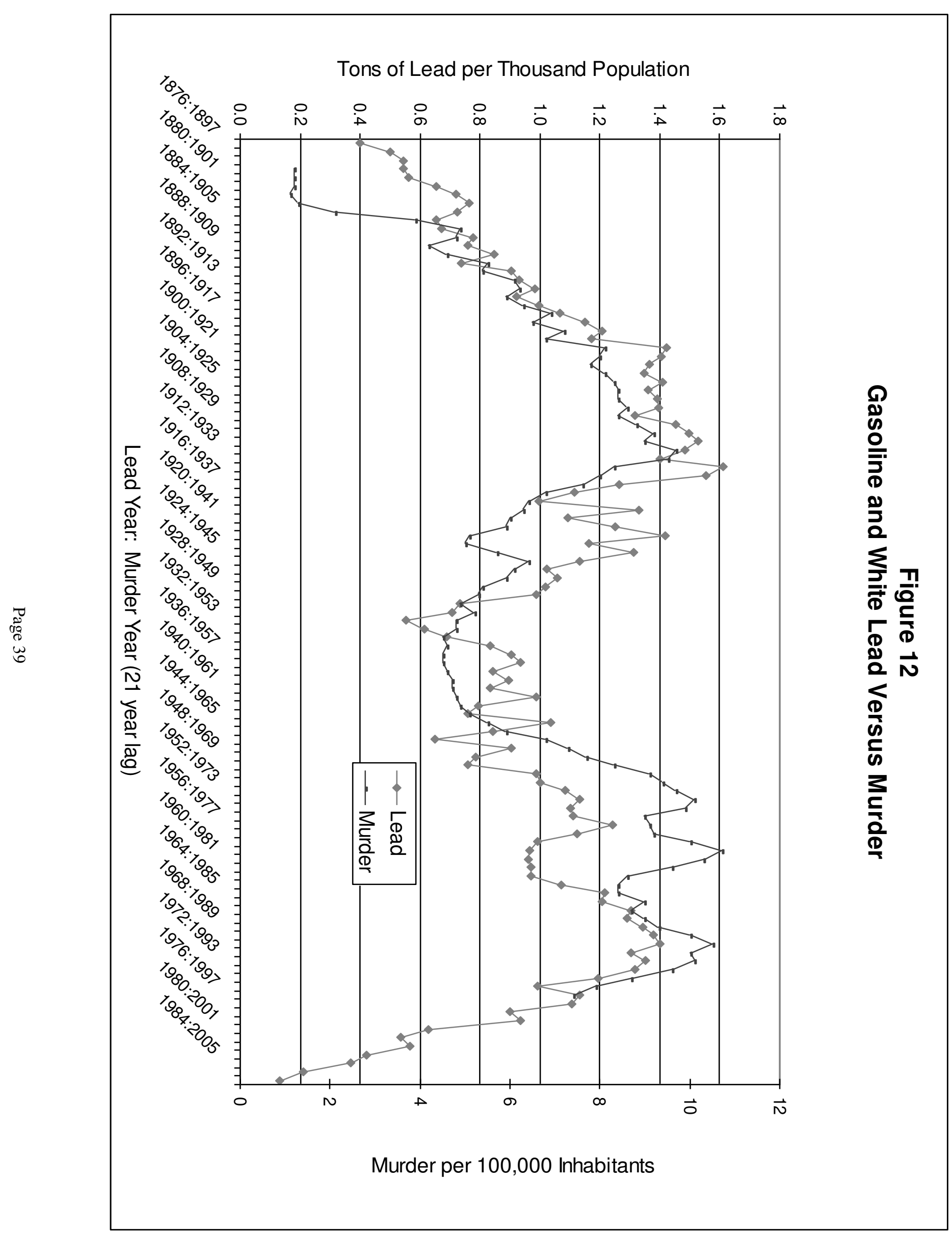




\section{DISCUSSION}

Changes in the median and $75^{\text {th }}$ percentile of CogAT IQ between 1984 and 1992 for children ages 9 and 10 are consistent with the Schwartz estimates of the IQ to blood lead slope and declines in the median and $25^{\text {th }}$ percentile of children's blood lead between NHANES II and III. The change in the $25^{\text {th }}$ percentile of CogAT IQ relative to the decline in the $75^{\text {th }}$ percentile of children's blood lead is also consistent with the higher slope suggested by Dudek and Merecz

for initial blood lead levels of $10 \mathrm{ug} / \mathrm{dL}$. This comparison in Table 8 assumes that the $25^{\text {th }}$ and $75^{\text {th }}$ percentiles of the 1992 CogAT norm comparisons (relative to 1984) are representative of $75^{\text {th }}$ and $25^{\text {th }}$ percentiles of children's blood lead, respectively. This assumption reflects the inverse relationship between IQ and blood lead and the strong correlation between blood lead and other variables associated with IQ. Children near the middle of the blood lead distribution are also likely to have average family income and parental education, and average IQ levels.

The median IQ for 9 and 10 year olds in the 1992 CogAT norm comparison increased at about twice the long-term trend reported by Flynn. Also, Table 10 shows that the increase in CogAT verbal and quantitative IQ for these ages in the 1992 norm comparison were approximately the same as gains in performance IQ. Over the same time period, however, increases in CogAT IQ for ages 12 and 13 were well below the long-term rate reported by Flynn, and children ages 15 and 16 actually showed declines in CogAT IQ. Furthermore, the 1984 norm comparison (relative to 1977) shows annual rates of increase in CogAT IQ for all ages that are well below the long-term trend reported by Flynn.

The covariate data in Figure 2 do not show any trends in family demographics, SAS, or maternal education that would explain both the sharp rise in IQ between 1984 and 1992 for children ages 9 and 10 and the relatively unchanged or declining IQ for other ages and time periods. The rising percentage of children living with mothers only and living in poverty from 
1970 to 1990 could be a factor in the 1984-92 decline in CogAT IQ for ages 15 and 16, but are not consistent with the sharp rise in CogAT IQ for ages 9 and 10. Also, there was no significant change from 1970 to 1990 in the percent of children living below 200 percent of the poverty level. The rising level of maternal education over recent decades could be a factor in rising IQ scores from 1984 to 1992 for children ages 9 and 10, but this trend is inconsistent with the decline in $\operatorname{Cog}$ AT IQ for children ages 15 and 16.

The 1984 to 1992 decline in CogAT IQ for children ages 15 and 16 and the increase for children ages 9 and 10 are both consistent with temporal changes in gasoline lead consumption. Gasoline lead use rose from 150,000 metric tons per year in the early 1960 s, to 250,000 metric tons in the early 1970 s, then fell back to 150,000 metric tons in the late 1970 s, and declined to about 50,000 metric tons per year in early 1980s. The CogAt IQ increase for children ages nine and ten in 1992 relative to the 1984 norm is consistent with the decrease in gasoline lead consumption from the early 1970s through the 1980s. The decrease in CogAT IQ for children ages 15 and 16 is consistent with the increase in gasoline lead consumption from the 1960s through the mid-1970s. The relatively slow rate of increase in IQ from 1984 to 1992 for children ages 12 and 13 may reflect the fact that children at this age in both population norms had relatively high gasoline lead exposure as young children. Finally, the slow rate of increase in IQ from 1977 to 1984 for all age groups may reflect continuing declines in average childhood paint lead exposure offset by rising gasoline exposure.

The association between gasoline lead exposure and IQ was also observed, but not recognized, by Herrnstein and Murray in their description of variations in IQ across age groups in the NLSY. Among these youths, ages 14 to 22 in 1980, higher scores were reported for the 20- to 22-yearolds than for the younger ages. By contrast, the 1992 CogAT results show that IQ decreased for older youths and increased for younger children. This contrast is consistent with the different 
years when these two groups of youths were born relative to the rise and fall of gasoline lead exposure. The NLSY youths ages 20 to 22 in 1980 were born in the late 1950s, while the younger NLSY teens were born in the mid-1960s when gasoline lead exposure was rising rapidly. The 1992 CogAT results reflect years when gasoline lead use was declining, so that older CogAT youths in 1992 were born during years with greater lead exposure.

\section{Regression Results}

Gasoline lead coefficients are highly significant $(p$-value $<.0000)$ in all of the crime and unwed pregnancy regressions, as is the Roe v. Wade variable in the unwed pregnancy regressions for ages 15-19. The overall unemployment rate and percentage of the population in high-crime age brackets (ages 15-24) was not significant in any of the crime regressions. The teen unemployment rate was significant in the regressions for rape, robbery, and for all violent crime.

In the case of pregnancies under age 15 and unwed pregnancies for other age brackets, the best-fit lag (highest $R^{2}$ and lowest $p$-value for lead) is equal to the median and mode age of unwed pregnancies for teens ages 15-17, and just above the median and mode ages for other age brackets. The median and mode ages of arrests for violent crime vary over time, and the broad age distribution results in medians that are several years higher than modes, but all of the crime regressions show a best-fit lag within the range of median and mode ages for arrests.

Although other social trends and government policies are often cited to explain the rise and fall in unwed pregnancy and crime rates over recent decades, the role of childhood lead exposure seems to be especially apparent in the best-fit lag structures for gasoline lead regressions. In the case of the unwed pregnancy regressions, the best-fit lag for each age bracket is consistent with changes in lead exposure in the first years of life. In the largest categories of violent crime, where the median and mode ages for aggravated assault tend to be several years older than 
the median and mode ages for robbery, the best-fit lag for assault is four years greater than the best-fit lag for robbery. The best-fit lags in Figures 3 through 11 clearly match the rise, peak, and decline in gasoline lead exposure, and most also reflect the temporary peak and plateau from the mid-1950s through the mid-1960s. The fit between these temporal patterns, with lags consistent with the known risks of lead exposure in the first years of life, provide striking visual support for the association between lead exposure and undesirable social behaviors.

The regression analysis of the temporal relationship between murder rates back to 1900 and gasoline and white lead exposure rates back to 1876 suggests that lead exposure may have influenced crime rates throughout this century. Although the $\mathrm{R}^{2}$ for this regression is not as high as for the gasoline lead regressions, the results still show that lead exposure rates are highly significant $(p-v a l u e<.0000)$ in explaining murder rates from 1900 to 1998 . The best-fit lag of 21 years, versus 18 years for the best-fit lag between murder rates and gasoline lead, is also consistent with the different lags between gasoline and paint lead and their greatest impact on blood lead levels. That is, gasoline lead consumption has been strongly associated with blood lead levels with a lag of just one to two months. Paint lead, by contrast, is likely to pose the more pervasive hazard several years after it is consumed in paint, when the older paint begins to flake and peel and create paint chip and lead dust hazards. 


\section{CONCLUSIONS}

Temporal trends in IQ, violent crime, and unwed pregnancy show a striking association with changes in blood lead levels and gasoline lead exposure for very young children. The trends in $I Q$ also suggest that the $I Q$ to blood lead slope increases at lower blood lead levels. Although crime and unwed pregnancy rates are obviously affected by a variety of factors, temporal trends in lead exposure appear to be a significant factor associated with subsequent trends in these undesirable social behaviors.

One of the interesting characteristics of this temporal trend analysis is that researchers can follow ongoing trends as the full effect of declining blood lead levels unfolds. If recent trends continue, then the additional decline in blood lead levels reported in NHANES III Phase 2 (19921994) should result in another rise in IQ on the next CogAT norm comparison, and the rise in CogAT scores should extend to older students by that time. If the association between gasoline lead and social behavior continues into the future, then violent crime and unwed teen pregnancy could show dramatic declines over the next five to ten years.

A continuation of these temporal trends would give cause to celebrate the success of public policy actions already taken to remove lead from gasoline and from paint. However, the association between lead exposure and undesirable social behavior is also a sobering new indication of the potential consequences of failing to address the remaining lead exposure hazards for young children. In particular, lead paint remains a hazard in more than 57 million pre-1980 homes, including more than 18 million pre-1940 homes that are likely to have high concentrations of lead in paint on a wide variety of surfaces (US Department of Housing and Urban Development). 
The number and percent of children exposed to lead paint hazards will certainly decline over time without any new public policy initiatives, due to the natural rates of demolition and renovation for older housing. In the absence of new policy initiatives to address lead paint hazards, however, a continuing temporal association between lead exposure and crime and unwed pregnancy suggests that lead exposure could still have life-altering consequences for countless Americans born over the next several decades. 


\section{ACKNOWLEDGEMENTS}

The author thanks Ashley Lare and Stephanie Carnes for their extensive assistance with data collection and computations; Peter Duback, Richelle Gipe, William Goldberg, and Kimberly Spence for their data collection assistance; and David Jacobs for many useful suggestions regarding revisions. Financial support from the US Department of Housing and Urban Development, Office of Lead Hazard Control is also gratefully acknowledged. 


\section{REFERENCES}

Alan Guttmacher Institute: "Special Report: US Teenage Pregnancy Statistics," 1998.

Banks, Ellen C.; Ferretti, Louise E.; Shucar, David W.; "Effects of low level lead exposure on cognitive function in Children: A review of behavioral, neuropsychological and biological evidence," Neurotoxicology, 18/1, 1997.

Centers for Disease Control and Prevention/ National Center for Health Statistics. Monthly Vital Statistics Report, Vol. 46, No. 11 (S), June 30, 1998.

Centers for Disease Control and Prevention. Morbidity and Mortality Weekly Report, Vol. 47, No. 47, "Abortion Surveillance: Preliminary Analysis - United States, 1996" December 4, 1998.

Centers for Disease Control and Prevention/ National Center for Health Statistics. "Births to Unmarried Mothers: United States, 1980-92" Vital and Health Statistics. June 1995.

Dudek, Bohdan; Merecz, Dorota. "Impairment of Psychological Functions in Children

Environmentally Exposed to Lead" International Journal of Occupational Medicine and Environmental Health. Vol.10, No.1, 1997.

Flynn, J.R. "The Mean IQ of Americans: Massive Gains" Psychological Bulletin, 95, 1984.

Flynn, J.R. "Massive IQ Gains in14 Nations: What IQ Tests Really Measure" Psychological Bulletin, 101, 1987.

Flynn, J.R. "IQ Gains Over Time" In R.J. Steinberg Encyclopedia of Human Intelligence. Macmillan, New York, 1994.

Gipe, Richelle. USGS Statistical Assistant - Lead. Personal communication. Nov 241998. Herrnstein, Richard; Murray, Charles. The Bell Curve: Intelligence and Class Structure in American Life. The Free Press, New York, 1994.

Koonin, Lisa M.; Smith, Jack; Ramick, Merrell; Strauss, M.A.; Hopkins, Frederic W. "Abortion Surveillance - United States, 1993 and 1994" JAMA: Women's Health. American Medical Association 1998. 
Mattiello, Joseph J. Protective and Decorative Coatings. Vol. I. John Wiley and Sons, New York, 1941.

Needleman, Herbert; Riess, Julie; Tobin, Michael; Biesecker, Gretchen; Greenhouse, Joel. "Bone Lead Levels and Delinquent Behavior" JAMA, February 7, 1996.

Needleman, Herbert. "Environmental Lead and Children's Intelligence" (Letter to the Editor) British Medical Journal, Vol.310, 1995.

Nriagu, Jerome. "The Rise and Fall of Leaded Gasoline" The Science of the Total Environment, 92, 1990.

National Research Council. "Measuring Lead Exposure in Infants, Children, and Other Sensitive Populations," Committee on Measuring Lead in Critical Populations, October, 1993.

Pirkle, James et al., "The Decline in Blood Lead Levels in the United States," JAMA, July 27, 1994.

Pocock, Stuart et al. "Environmental lead and children's intelligence: a systematic review of the epidemiological evidence," BMJ, Volume 309, November 1994.

Schwartz, Joel. "Low-Level Lead Exposure and Children's IQ: A Meta-Analysis and Search for a Threshold," Environmental Research, April, 1994.

Schwartz, Joel; Pitcher, Hugh. "The Relationship Between Gasoline Lead and Blood Lead in the United States," Journal of Official Statistics, Vol. 5 No. 4, 1989.

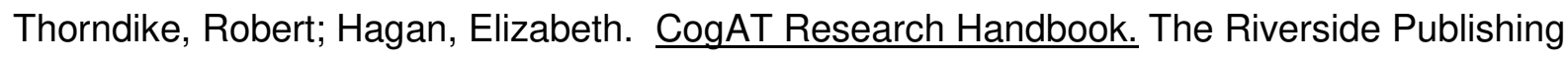
Company, 1997.

US Bureau of Labor Statistics, "Labor Force Statistics from the Current Population Survey."

US Department of Commerce. Historical Statistics of the United States: Colonial Times to 1970 Part I.

US Department of Commerce. Statistical Abstract of the United States, $1973-1975,1977$, 1978, 1980, 1990, and 1996. 
US Department of Health and Human Services: Trends in the Well-Being of America's Children and Youth: 1996.

US Department of Health and Human Services: $\underline{\text { Health, United States, } 1995 .}$

US Department of Housing and Urban Development, Comprehensive and Workable Plan for the Abatement of Lead Paint in Privately Owned Housing, December 7, 1970.

US Department of Justice, Federal Bureau of Investigation, "Number of offenses per 100,000 Inhabitants," Crime Index Rate, United States, 1960-1996, and "Part I and Part II Arrests," provided by Programs Support Section, Criminal Justice Information Services (CJIS) Division, United States, 1960-1996.

US Environmental Protection Agency. Air Quality Criteria for Lead, Volume I of IV, June 1986. US Geological Survey, Minerals Information, US Consumption - Tetraethyl Lead, White Lead, and Red Lead/Litharge, provided by Data Collection and Coordination Section.

Ventura, Stephanie J.; Mathews, T.J.; and Curtin, Sally C., "Declines in Teenage Birth Rates, 1991-1997: National and State Patterns," National Vital Statistics Reports, Ceenters for Disease Control and Prevention, Volume 47, Number 12. 